\title{
FLUOROQUINOLONES ANTIBIOTICS ADSORPTION ONTO POLYMER COATED MAGNETIC NANOPARTICULAR ACTIVATED CARBON
}

\author{
Mehmet Uğurlu ${ }^{* 1,2}{ }^{凶}$, Huseyn Osman ${ }^{1}$, Ali imran Vaizoğullar ${ }^{3}$, Abdul Chaudhary ${ }^{4}$ \\ ${ }^{* 1}$ Department of Chemistry. Faculty of Science and Art. Ağrı İbrahim Çeçen University. 04000 Ağrı. \\ Turkey \\ ${ }^{2}$ Department of Chemistry. Faculty of Science. Muğla Sitki Kocman University. 48000 Muğla. \\ Turkey \\ 3 Vocational School Healthcare Med Lab Program Muğla Sitki Kocman University. 48000 Muğla. \\ Turkey \\ ${ }^{4}$ Department of Life Sciences, College of Health, Medicine and Life Sciences, Brunel University \\ London, UB8, 3PH, UK
}

DOI: https://doi.org/10.29121/IJOEST.v5.i2.2021.172

Article Type: Research Article

Article Citation: Mehmet Uğurlu, Huseyn Osman, Ali imran Vaizoğullar, and Abdul Chaudhary. (2021). FLUOROQUINOLONES ANTIBIOTICS ADSORPTION ONTO POLYMER COATED MAGNETIC NANOPARTICULAR ACTIVATED CARBON. International Journal of Engineering Science Technologies, 5(2), 81-104.

https://doi.org/10.29121/IJOEST.v 5.i2.2021.172

Received Date: 13 March 2021

Accepted Date: 11 April 2021

Keywords:

Activated Carbon

Adsorption

Magnetic Adsorbent

Fluoroquinolone (FLQ

Isotherm

\section{ABSTRACT}

The present study investigated the adsorption of molecular fluoroquinolone (FLQ) from aqueous solution onto active carbon (AC), magnetic activated carbon (MagAC), styrene-butadiene styrene magnetic activated carbon (SBS/MagAC) and poly charbon magnetic activated carbon (PC/MagAC) as adsorbent materials. The process optimization was carried by investigating the effects of $\mathrm{pH}$, temperature, solid-liquid ratio, adsorbent type and initial concentration of FLQ. The data showed that adsorption reached equilibrium in as little as one hour. The adsorption cacapcity was comparatively less at low $\mathrm{pH}$ values than at approximately $\mathrm{pH}$ 5.0. The results also showed that the polymer coated magnetic materials did not perform very well at high $\mathrm{pH}$ values. However, all the materials performed well at room temperature when the situation was examined in terms of kinetics. It was also observed that AC, SBS/MagAC and PC/MagAC are more effective than MagAC to remove FLQ from aqueous medium. The kinetic data support pseudo-second-order model $(\mathrm{r} 2 \geqslant 0.95)$ but showed very poor fit for pseudo-first-order model (r2 $\leq$ 0.90). Intra-particle model also showed that there were two separate stages in sorption process, namely, external diffusion and the diffusion of inter-particle. Adsorption isotherms for all adsorbends were fitted to Langmuire models more effectively than Freundlich models ( $\mathrm{r} 2 \geqslant 0.98)$. Thermodynamics parameters such as; free energy $(\Delta \mathrm{G} 0)$, enthalpy $(\Delta \mathrm{H} 0)$ and entropy $(\Delta \mathrm{S} 0)$ were also calculated. In conclusion, our results revealed that FLQ can be removed more easily from the aqueous medium by using magnetic and polymeric material. 
Fluoroquinolones Antibiotics Adsorption onto Polymer Coated Magnetic Nanoparticular Activated Carbon

\section{INTRODUCTION}

Antibiotics are widely used to treat or prevent human and animal diseases, but antibiotics resistance has become a major global public health issue in recent years [1] Fluoroquinolone antibacterial agents (FLQs) are a group of potent synthetic antibiotics that are widely used in human and veterinary medicines [2]. The widespread presence and potential toxicities of FLQs necessitate a better understanding of their environmental fate to properly assess their risks. In this sense, the identification and determination of these compounds play a very important role on the development of new wastewater treatment technologies in order to reduce the micropollutants concentration levels in wastewaters. Previously, biodegradation [3], photodegradation [4] and adsorption [5], [6] processes have been used for the removal of many organic chemicals, including FLQ, from aquoes streams. However, some of these methods are not effective in the removal of FLQ as the occurrence of this chemical in natural environment can affect the selection of genetic variants of microorganisms, result in the development of drug resistant bacteria or pathogens, and induce a risk to the ecosystem and human health. Therefore, the conventional primary and secondary water treatment plants can not remove or degrade FLQ efficiently. Hence, there is a need to develop and optimise a feasible and effective method for the removal of FLQ from aqueous effluent streams [7], [8]. In the literature study, fluoroquinolone antibacterial agents (FLQs) were found to adsorb strongly to goethite with 50-76\% of the added FLQ adsorbed under the experimental conditions [9], [10]. Another study involveed the removal of flumequine from water by activated carbon fixed-bed columns and represents the first study of this emerging contaminant in fixed bed adsorption [11]. The adsorption of flumequine (fluoroquinolone antibiotic) and copper (II) on an alkaline soil sample was studied at macroscopic and molecular scales. The retained antibiotic amount onto the soil surface increases (from 2- to $>20$-fold) with the copper concentration due to the formation of a $\mathrm{Cu}$ (II)-flumequine ternary surface complex, which leads to the accumulation of flumequine into soils [12]. The glycerol-based carbon materials $\left(\mathrm{GBCM}_{200}, \mathrm{GBCM}_{300}\right.$ and $\left.\mathrm{GBCM}_{350}\right)$ was used as adsorbents for the removal of the antibiotic compounds flumequine and tetracycline from aqueous solution [13].

As can be seen briefly from the explanations above, many different methods can be used for the removal of FLQ from aqueous solution. Among these, adsorption is one of the most effective methods and is suitable for developing countries due to low chemicals and materials consumption [14]. In particular, adsorption has become a most widely used method for removing micropollutants, especially hydrophilic compounds such as FLQ, because the adsorbent can be easily modified with increased surface charge. However, the selectivity of the adsorption method is not very good, requiring a specific adsorbent of the surface modification of the common adsorbent [15]. The modification of the adsorbent is needed to increase the efficiency and selectivity of FLQ removal by natural adsorbents with a small specific surface area. The most problematic and undesirable situation in the adsorption process is the removal and recovery of nano-based adsorbent materials from the reaction systems. These nano-based materails can be realesed into the ecosystem and must be removed for safe disposal. It has been reported that this difficulty can be solved by simply and effectively exposing the reaction system to external magnetic fields. However, this appaocah can only be used for the separation of magnetic nanoscale materials [16], [17]. In literature studies, iron-based magnetic nanopowders are most widely used and preferred as material candidates due to their magnetic and other distinctive properties [18], [19].

The application of modified activated carbon, containing iron particles, is the commonly used adsorbent to remove a varirty of environmental contaminats from various waste streams. For example, activated carbon (AC) containing iron components $\left(\mathrm{FeO}, \mathrm{Fe}_{2} \mathrm{O}_{3}\right.$ or $\left.\mathrm{Fe}_{3} \mathrm{O} 4\right)$ have been recently used for the treatment of food waste [20], effluent streams containing various organic compounds [21], $\mathrm{Cr}$ (VI) [22], antibiotics [23], different heavy metals and As(V) [24]. In addition, AC can also be used for different purposes after processing with certain polymeric materials. In the literature studies, effective mercury removal was carried out using polymer coated activated carbon. In this study, polysulfide-rubber (PSR) polymer, a sulfur-rich compound, was used to increase affinity to remove mercury with activated carbon. $\mathrm{Hg}-\mathrm{Cl}$ and $\mathrm{Hg}$-S interactions on the activated carbon surface of the chemical bond with mercury have been reported [25].

In all previous studies, it is observed that there is no electrical charge on AC powders and it cannot be controlled by electric or magnetic fields. It can also create secondary contamination after adsorption processes and the presence of magnetic charge would help to trap, restore and recycle AC and prevent its release into the environment. In literature study, AC was obtained from rice husk and then modified using magnetic material. The resultant adsorbent material has high surface area $\left(770 \mathrm{~m}^{2} / \mathrm{g}\right)$ and $2.78 \mathrm{emu} / \mathrm{g}$ saturation magnetization (Ms) with $23 \% \mathrm{Fe}_{3} \mathrm{O}_{4}$ coating. The material has high adsorption capacity and was successfully used for the removal of Methylene Blue (MB) 
[26]. In another study, it has been reported that activated carbon modifede using magnetic nanoparticle $\left(\mathrm{AC}-\mathrm{Fe}_{3} \mathrm{O}_{4}\right.$ MNPs) have additional advantages over the conventional AC materials. These modified AC materials are effective adsorbent materials for the removal of various contaminants such as aniline from both water and wastewater streams [27].

We now report on the synthesis, characterisation and application of activated carbon modified with magnetic nanoparticles for the removal of FLQ from aqueous systems. Firstly. samples of active carbon (AC), magnetic acticated carbon (MagAC), styrene-butadiene styrene magnetic activated carbon (SBS/MagAC) and poly charbonat magnetic activated carbon (PC/MagAC) were synthesized and characterized as new adsorbents. In FLQ adsorption experiments, temperature, solid-liquid ratio, adsorbent type, initial concentrations of FLQ and solution pH were investigated by carrying out experiments on a constant shaker under similar experimental condistions. The efficiency of different adsorbents were calculated and compared by inverstigating adsorption kinetics and thermodynamic parameters.

\section{Experimental}

\subsection{MATERIALS AND PREPARATION OF ADSORBENTS}

\subsubsection{ACTIVATED CARBON(AC)}

The activated carbon samples used in the study were obtained commercially, Sigma-Aldrich, 242276-300MG, Other iron samples were also obtained commercially (ZAG, ZK.100380.1000) and prepared according to literature studies [28].

\subsubsection{MAGNETIC ACTIVATED CARBON (MAGAC)}

$\mathrm{FeCl}_{3}(1.08 \mathrm{~g})$ and $\mathrm{FeCl}_{2}(2.40 \mathrm{~g})$ were added to $150 \mathrm{ml}$ of distilled water and shaken at $60-65^{\circ} \mathrm{C}$ for $1 \mathrm{hour}$. $\mathrm{A} 5 \mathrm{~g}$ of activated carbon was then added to these samples and shaken at the same temperature for 2 hours. In the final step, $5 \mathrm{~g}$ of $\mathrm{NaOH}$ was added while stirring the mixture for $1 \mathrm{~h}$ and aged at overnight. After washing several times with distilled water. it was dried in an oven to a constant weight.

\subsubsection{STYRENE-BUTADIENE STYRENE MAGNETIC ACTIVATED CARBON (SBS/MAGAC)}

SBS (1.0g) + THF/DMF 50ml (30:20) samples were prepared and stirred at $60-65{ }^{\circ} \mathrm{C}$ for 2 hours. Then $5 \mathrm{~g}$ of activated carbon was added to the same temperature for one hour. To this mixture, $\mathrm{FeCl}_{3}(1.08 \mathrm{~g})+\mathrm{FeCl}_{2}(2.40 \mathrm{~g})$ was added and the mixture was stirred at $60-65^{\circ} \mathrm{C}$ for 2 hours. In the final step, $5 \mathrm{~g}$ of NaOH was added to the samples stirred for 1 hour and allowed to stand overnight. These samples were washed several times with distilled water, then filtered and dried to a constant weight in an oven.

\subsubsection{POLY CHARBONAT MAGNETIC ACTIVATED CARBON (PC/MAGAC)}

PC (1.0 g) and THF/DMF $50 \mathrm{ml}$ (30:20) samples were taken and stirred at $60-65^{\circ} \mathrm{C}$ for $2 \mathrm{~h} .5 \mathrm{~g}$ of activated carbon was added and stirred at the same temperature for one hour. $\mathrm{FeCl}_{3}(1.08 \mathrm{~g})+\mathrm{FeCl}_{2}(2.40 \mathrm{~g})$ was then added and the mixture was stirred for 2 hours at $60-65^{\circ} \mathrm{C}$. In the final step, $5 \mathrm{~g}$ of $\mathrm{NaOH}$ was added and the mixture was stirred for 1 hour. After washing several times with distilled water, the filtered samples were dried to a constant weight in an oven.

\subsection{CHARACTERIZATION PROCESSES}

The characterization of the adsorbents were carried out using Perkin Elmer Lambda 35 UV-Vis Spectrophotometer, Perkin Elmer Pyris 1 for Thermogravimetric Analyzer, Perkin Elmer Diamond for Differential Scanning Calorimeter, Jsm-7600f for Scanning Electron Microscope, Rigaku-Smart-Lab-X-Ray Diffractometer for 
XRD, Fourier Transform Infrared (FTIR) Spectroscopy, Thermo Scientific Nicolet Is10 and Micromeritics TriStar II PLUS for BET analysis.

\subsection{ADSORPTION EXPERIMENTS AND DETERMINATION OF FLUOROQUINOLONE (FLQ)}

The standard stock FLQ solution was prepared by dissolving $0.02 \mathrm{~g}$ of FLQ in $100 \mathrm{ml}$ EtOH using a magnetic stirrer and the final volume was made to $1,000 \mathrm{ml}$ by adding $900 \mathrm{ml}$ of pure water. Adsorption experiments were carried out by using $200 \mathrm{ml}$ of FLQ solution containing $50 \mathrm{mg} / \mathrm{L}$. Changes in FLQ concentration were determined before and after the adsorption process with a UV spectrophotometer at a constant wavelength of $244 \mathrm{~nm}\left(\lambda_{\max }\right.$ for FLQ). All concentrations were determined by using the calibration curve. Commercially activated granular activated carbon (AC), MagAC, SBS/MagAC and PC/MagAC magnetic adsorbents were used in the experimental study. All adsorption experiments (except experiments examining the $\mathrm{pH}$ effect) were carried out at natural pH. Temperature, solid-liquid ratio, adsorbent type, initial concentrations and solution $\mathrm{pH}$ were selected as parameters to be investigated for the adsorption studies. In experiments examining the $\mathrm{pH}$ effect, the $\mathrm{pH}$ of the solution was adjusted using dilute $\mathrm{HCl}$ and $\mathrm{NaOH}$ solutions and monitored throughout the exoperiment using a pH meter (WTW-Germany. PH 330i). Adsorption experiments were carried out on a constant shaker with a cooling effect. The structure of all synthesized materials, adsorption test apparatus and FLQ are shown in Figure 1, Figure 2a and 2b.

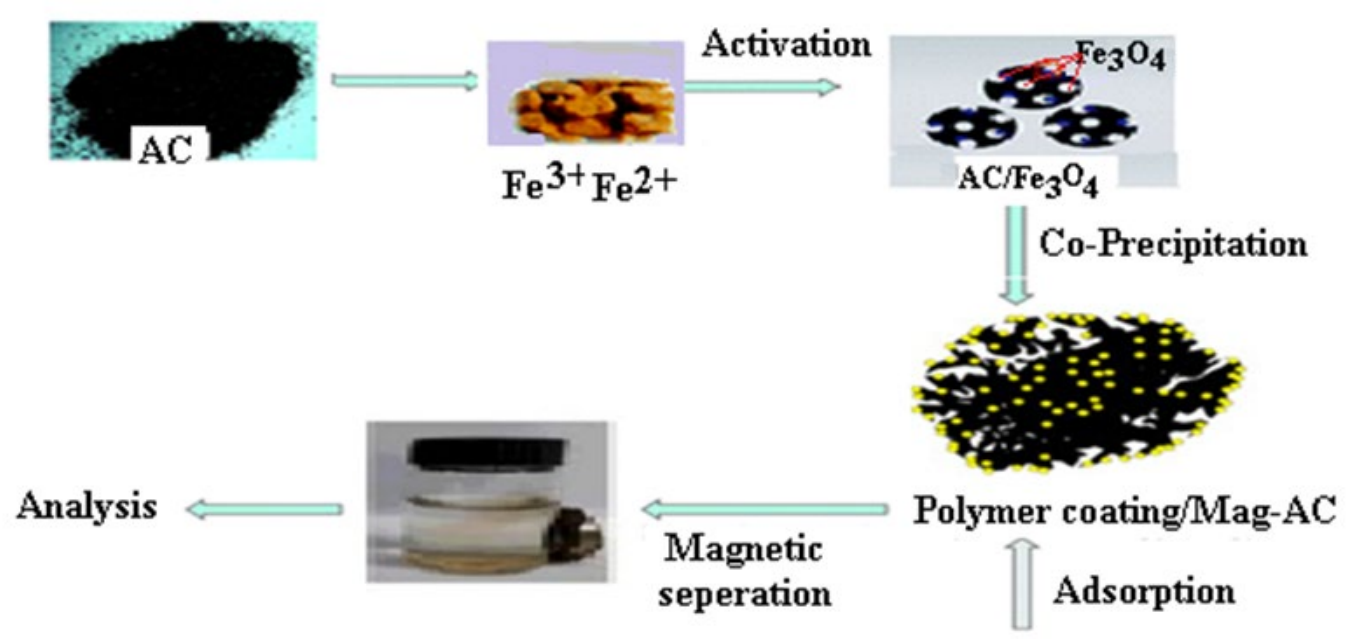

Phenol

Figure 1: Synthesis of magnetic materials and general flow chart of experimental design
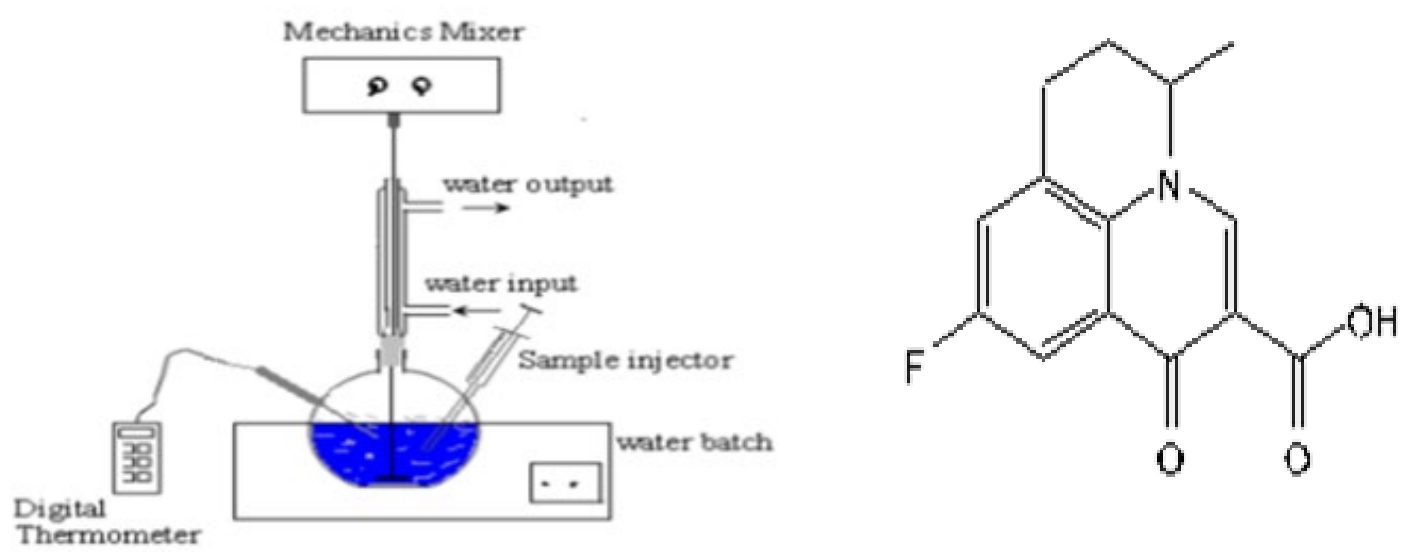

Figure 2: Adsorption experiment setup (a) and the chemical structure of FLQ (b) 


\subsection{ADSORPTION KINETICS}

There are various kinetic models that characterize the adsorption process which determine what kind of mechanism plays a role in the adsorption of the pollutant to the adsorbent surface. The kinetic study was performed using various kinetic models. The pseudo-first-order (Eq.(1)) and pseudo-second-order (Eq.(2)) kinetic models proposed by Lagergren [29] and Ho and McKay [30] are described in the following equations respectively [31].

$$
\begin{aligned}
& \log \left(q_{e}-q_{t}\right)=\log \left(q_{e}\right)-\frac{k_{1}}{2.303} t \\
& \frac{t}{q_{t}}=\left[\frac{1}{k_{2} q_{e}^{2}}\right]+\frac{1}{q_{e}} t
\end{aligned}
$$

In the above equations, qe is the amount of adsorbed substance (mg/g) per gram of adsorbent at equilibrium, qt is the amount of adsorbed substance $(\mathrm{mg} / \mathrm{g})$ per gram of adsorbent at any instant. The $\mathrm{k}_{1}$ and $\mathrm{k}_{2}\left(\mathrm{~min}^{-1}\right)$ are the adsorption rate constants of the pseudo 1 st and 2 nd order kinetic models respectively.

The intraparticle diffusion equation proposed by Weber and Morris is given as follows [32].

$$
q_{t}=k_{i} t^{1 / 2}+C
$$

Here $\mathrm{c}$ and $\mathrm{ki}$ (in $\mathrm{mg} / \mathrm{g} \min ^{1 / 2}$ ) represent the intercept and the intra-particle-diffusion rate constant. The halftime of adsorption $t_{1 / 2}$ is defined as the time required for adsorption to reach half the equilibrium value. This time is generally used as a measure of adsorption rate and is calculated with the help of Equation (4).

$$
t_{1 / 2}=\left[\frac{1}{k_{2} q_{e}}\right]
$$

\subsection{ADSORPTION ISOTHERMS}

It is extremely important to understand the surface properties and affinity of adsorbent and its interaction with the adsorbate. In this study, the adsorption isotherms were conducted at optimized experimental conditions. The physicochemical data to recognize the adsorption mechanism was interpreted using both Langmuir and Freundlich isotherm models. The following equations (Eq.(5) and Eq.(6)) represent the Langmuir and Freundlich isotherm models [33].

Linear state of this equation

$$
\begin{aligned}
& \frac{C_{e}}{q_{e}}=\frac{1}{b Q_{0}}+\frac{C_{e}}{Q_{0}} \\
& \ln q_{e}=\ln K_{F}+\frac{1}{n} \ln C_{e}
\end{aligned}
$$

The above equations. $\mathrm{Q}_{0}$ (in $\mathrm{mg} / \mathrm{g}$ ) is the maximum monolayer adsorption capacity. $\mathrm{C}_{\mathrm{e}}$ (in $\mathrm{mg} / \mathrm{L}$ ) is the equilibrium concentration. b. $\mathrm{K}_{\mathrm{F}}$ and $\mathrm{n}$ are respectively called the Langmuir and Freundlich constants.

\subsection{ADSORPTION THERMODYNAMICS}

For the adsorption process, enthalpy, entropy and free energy changes can be determined by the equilibrium constant. These thermodynamic parameters are shown in the following equations (Eq. (7) and Eq. (8) [33].

$$
\begin{aligned}
& \Delta G^{0}=-R T \ln K_{e} \\
& \ln K_{e}=-\frac{\Delta H^{0}}{R T}+\frac{\Delta S^{0}}{R}
\end{aligned}
$$


Here. $\Delta \mathrm{G}^{\mathrm{o}}$ standard Gibbs free energy. $\Delta \mathrm{H}^{\mathrm{o}}$ standard enthalpy and $\Delta \mathrm{S}^{\mathrm{o}}$ standard entropy. $\Delta \mathrm{H}^{\mathrm{o}}$ and $\Delta \mathrm{S}^{\mathrm{o}}$ are calculated from the slope of the graph of $1 / \mathrm{T}$ versus $\ln K e$ and the cut-off point. respectively. Adsorption equilibrium constant can be calculated using the following equation.

$$
K_{e}=\frac{C_{a d s}}{C_{e}}
$$

Here, $\mathrm{C}_{\mathrm{ads}}$ is the concentration $(\mathrm{mg} / \mathrm{L})$ of the adsorbed substance at equilibrium and $\mathrm{C}_{\mathrm{e}}$ is the concentration of the substance remaining in solution at equilibrium $(\mathrm{mg} / \mathrm{L})$.

\section{DISCUSSION AND CONCLUSION}

\subsection{CHARACTERIZATION OF THE SYNTHESIZED ADSORBENT MATERIALS}

All adsorbent materials (AC, MagAC, SBS/MagAC and PC/MagAC) were characterised using various analytical techniques, for example, FTIR, SEM, EDS, XRD, TGA, DSC and BET. All the related evaluations and comparisons for different adsorbent materials are given in the following subsections.

\subsubsection{SEM/EDS IMAGES AND BET ANALYSIS}

The morphological structure of adsorbents can give specific information about the adhesion characteristics and mechanism. The SEM and EDS results of different adsorbents are given in Fig 3.

From Fig 3, when the SEM images of the activated carbon are examined, a distinct porous structure is seen, with many cavities, and its outer surfaces are recessed and protruding. In MagAC and PC/MagAC materials, it is seen that the iron and polymers species attach to the porous surface of the activated carbon and the particles inside. SEM image of SBS/MagAC material show a clearer appearance than the other samples in which a significant change is observed. This is thought to be the result from the interaction of polymers with the pores of the activated carbon.
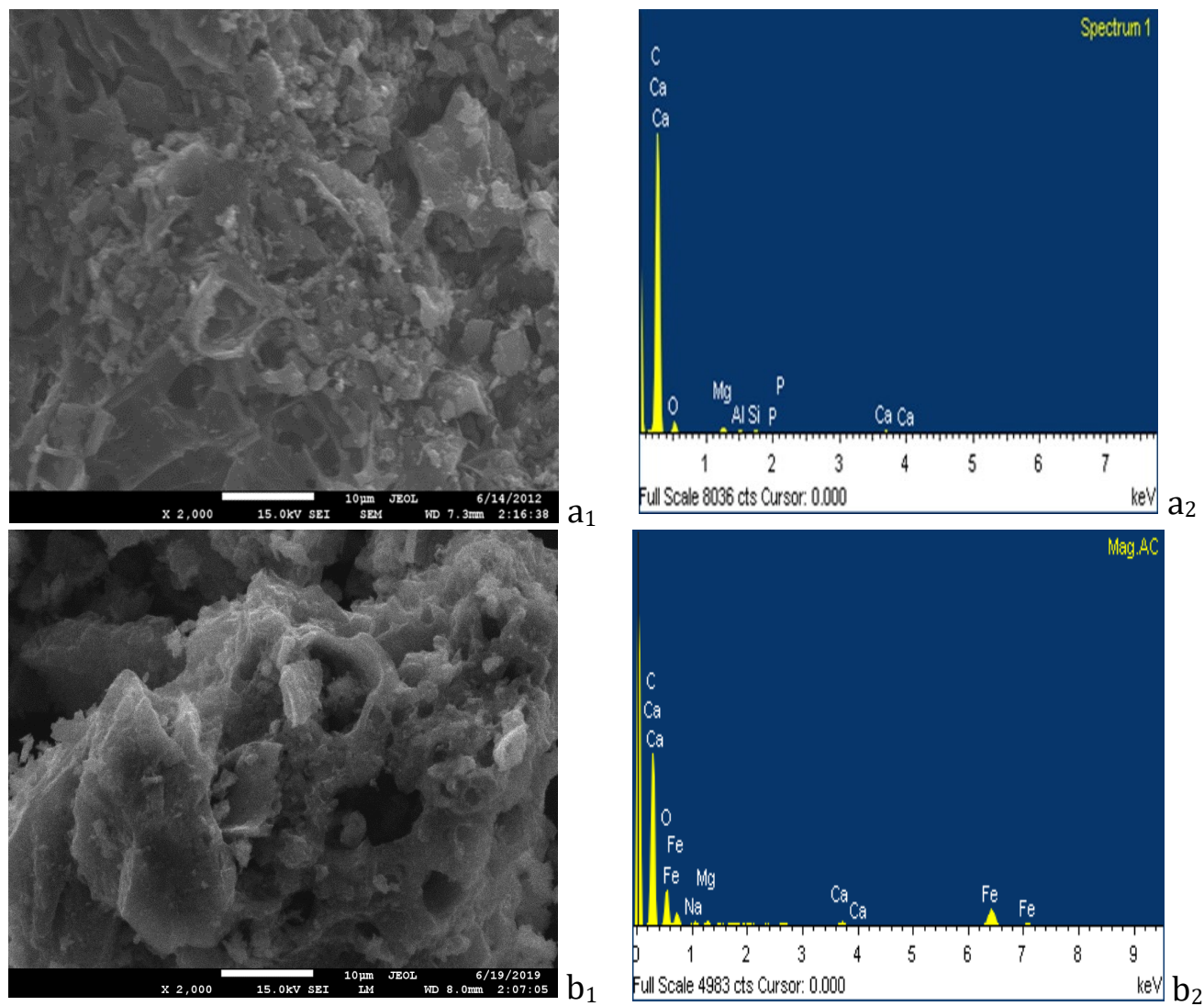

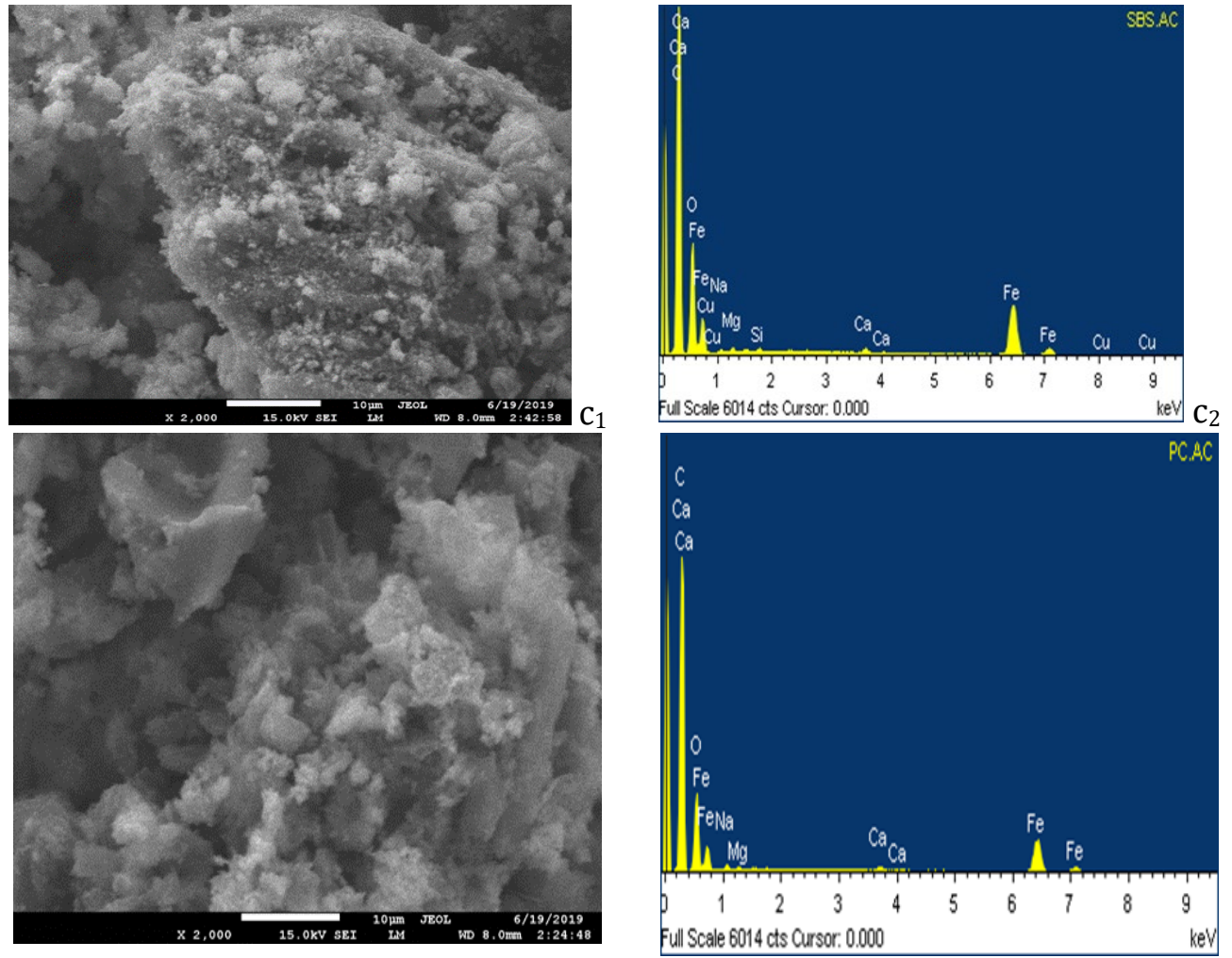

Figurer 3: SEM and EDS images of adsorbent materials a) AC, b) MagAC, c) SBS/MagAC, d) PC/MagAC

In order to obtain the information about the element structure of adsorbent materials, EDS analysis was performed from SEM image. As shown in the EDS graph given in Fig 3, it is seen that $\mathrm{Ca}, \mathrm{Fe}$, $\mathrm{C}$, and $\mathrm{O}$ elements are present predominantly on the surface of the adsorbents except activated carbon and with small amounts of Na and Mg elements. Trace amounts of $\mathrm{Cu}$ and Si elements are also partially observed in SBS/MagAC material. In addition, when the EDS analysis was examined the highest amount of $\mathrm{Ca}$ and $\mathrm{C}$ elements were found in these samples. In addition, activated carbon samples obtained by using various polymeric materials and surface and pore size changes are given in Table 1.

Table 1: Changes in surface and pore size by loading magnetic and polymeric materials on the surface of activated carbon.

\begin{tabular}{|c|r|r|r|c|}
\hline Surface and Pore Parameters & AC & MagAC & SBS/MagAC & PC/MagAC \\
\hline \multicolumn{2}{|c|}{ Surface areas $\left(\mathrm{m}^{2} / \mathrm{g}\right)$} \\
\hline Single point surface area & 695.459 & 642.54 & 248.49 & 301.18 \\
\hline BET Surface Area & 687.751 & 636.86 & 251.31 & 304.56 \\
\hline Langmuir Surface Area & 912.379 & 845.74 & 339.63 & 412.56 \\
\hline t-Plot Micropore Area & 395.999 & 354.35 & 82.66 & 89.38 \\
\hline t-plot Surface Area & 291.751 & 291.51 & 168.65 & 215.18 \\
\hline Pore volume (cm 3 /g) & & & & \\
\hline Total pore volume from a single point & 0.571 & 0.598 & 0.285 & 0.328 \\
\hline t-Plot micropore volume & 0.181 & 0.157 & 0.036 & 0.039 \\
\hline BJH Adsorption cumulative pore volume & 0.339 & 0.396 & 0.221 & 0.261 \\
\hline BJH Desorption cumulative pore volume & 0.376 & 0.432 & 0.234 & 0.280 \\
\hline Pore size (nm) & & & & \\
\hline Adsorption average pore width (4V/A with BET) & 3.323 & 3.759 & 4.551 & 4.311 \\
\hline BJH Adsorption average pore diameter (4V/A) & 7.137 & 8.020 & 8.122 & 8.221 \\
\hline BJH Desorption mean pore diameter (4V/A) & 5.472 & 6.163 & 6.081 & 6.191 \\
\hline
\end{tabular}


As can be seen in Table 1, considering the surface area of $A C$ and synthesized materials, it is observed that all surface area parameters follow as AC $>$ MagAC $>\mathrm{PC} /$ MagAC $>$ SBS/MagAC. A similar situation is observed when pore volume is examined. When the pore size data are evaluated, the opposite situation is observed. This is attributed to the polymer material reaching and penetrating into the interior of the pores.

\subsubsection{XRD IMAGES}

XRD analysis of magnetic materials obtained with various polymeric materials using activated carbon samples are given in Fig 4.

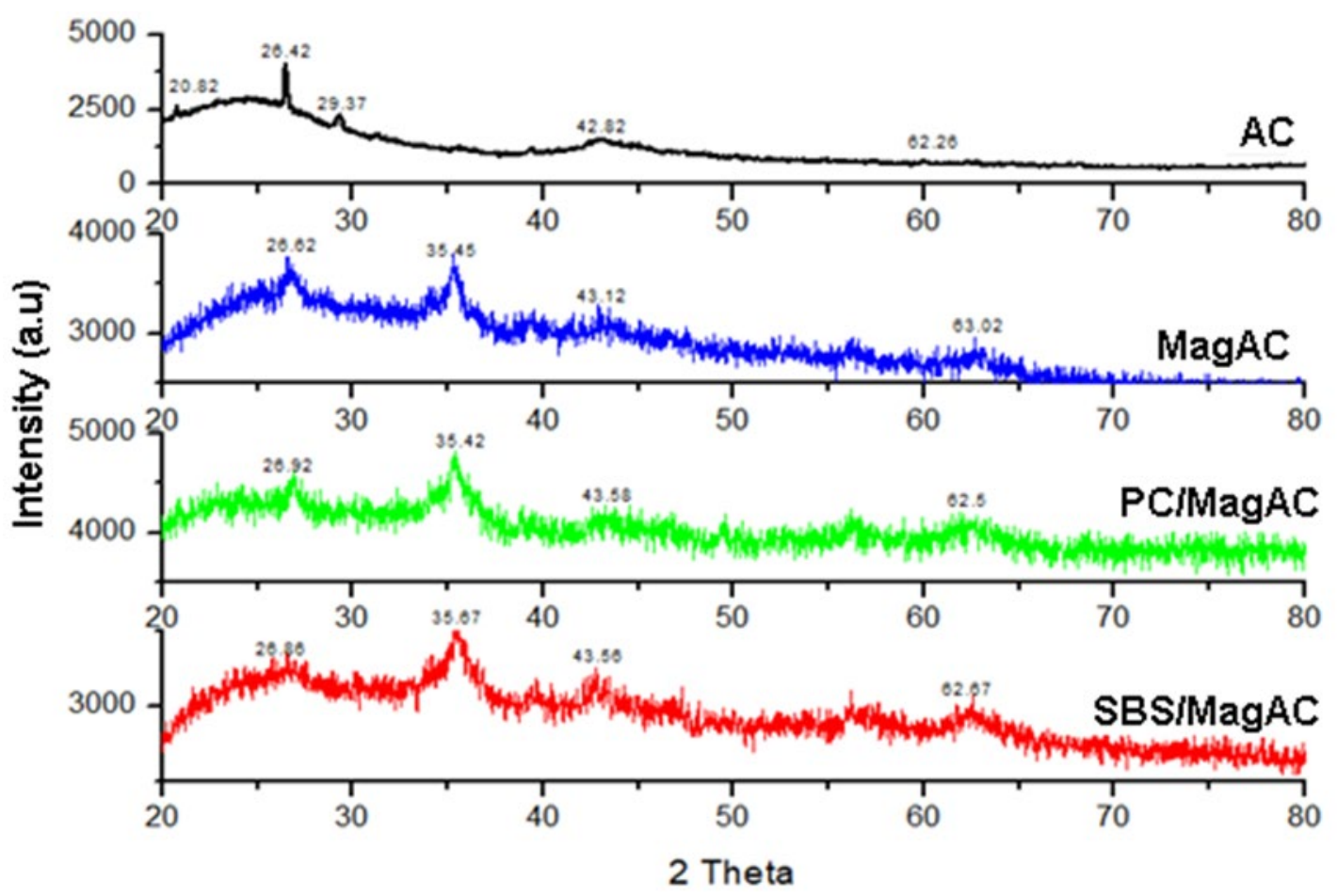

Figure 4: XRD images of different adsorbent materials

Fig 4 shows the XRD spectra of activated carbon and activated carbon based catalysis samples. When XRD spectra of pure activated carbon are examined, the characteristic 2 theta degree with $20.82^{\circ}, 26.42^{\circ}, 29.37^{\circ}, 42.82^{\circ}$ and $62.26^{\circ}$ are seen with sharp peaks. This shows that AC has a regular crystal structure. The diffraction peaks at 26.42 and 42.82 shows (002) and (100) planes respectively. The highest peak intensity was observed at $26.42^{\circ}$. This shows that AC grows in the direction of the surface (002) surface [34]. In addition, when compared with other synthesized samples, significant decreases in peak intensity are observed. This shows that AC samples with partially crystalline structure tend to turn into amorphous structure over time. In other words, the diffraction peaks in the other samples except AC were slightly wider. The decrease in the sharp peak intensities of AC indicates that the composite components shift to a little more amorphous structure and also indicates that the particle size decreases to some extent [35].

When the diffraction peaks of the MagAC sample with magnetic content were examined, a diffraction peak at $35.45^{\circ}$ which iron components was observed besides the characteristic activated carbon peaks. In all synthesized samples except activated carbon, it is observed that iron peaks are formed as a result of treatment with strong base to ensure complete precipitation of iron ions. The angle of about $35^{\circ}$ is seen in each sample. This shows that there is no change in the crystal structure of the PC and SBS used on the Iron components. When we look at SBS/MagAC sample, it is seen that the main diffraction peak intensity decreases and Full Width at Half Maximum (FWHM) value increases. This suggests that SBS provides an effective dispersion on AC. This result shows that the particles of polymeric properties are synthesized with high efficiency of activated carbon samples and that an active dispersion of other magnetic and polymeric components on AC surface is provided. 


\subsubsection{TGA ANALYSIS}

The relationship between temperature and mass loss was investigated by using TGA analysis of magnetic materials obtained with various polymeric materials using activated carbon samples and is given in Fig 5.

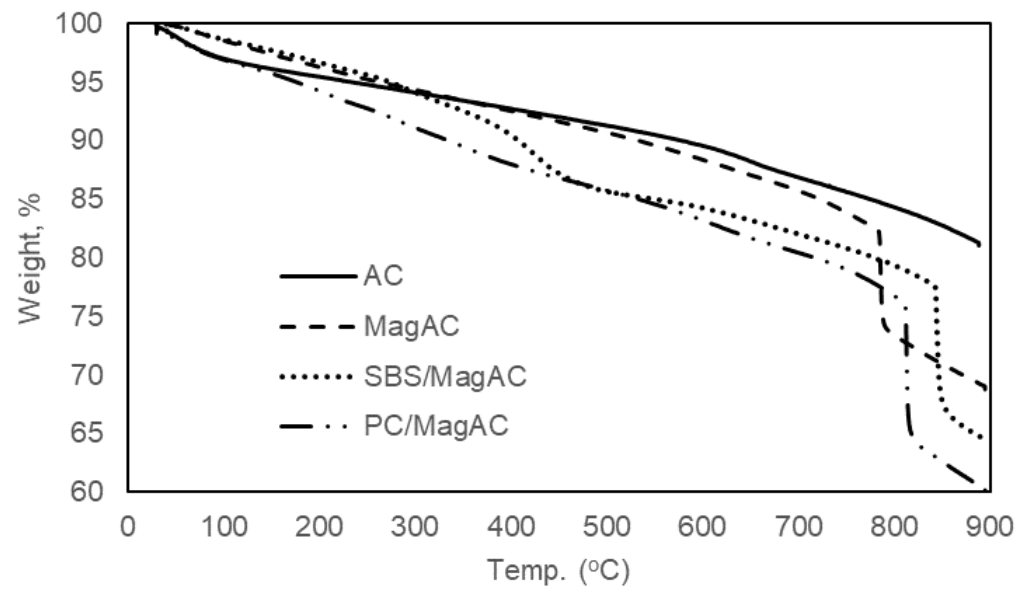

Figure 5: TGA results of AC, MagAC, SBS/MagAC, and PC/MagAC adsorbents

In short, TGA is a method used to examine the ability of a substance to maintain its mass (thermal stability) under various conditions. In other words, it is the continuous monitoring of the changes in the mass of the substance depending on the temperature and evaluating this as a function of the temperature. The data in Fig 5 show that the TGA values of AC generally lose mass with increasing temperature and a significant peak change occurs. Here, a significant peak change was observed at MagAC and PC/MagAC samples at approximately $800^{\circ} \mathrm{C}$ and at the other SBS/MagAC samples at $850^{\circ} \mathrm{C}$. This shows that the thermogravimetric method is dynamic that the system will never reach equilibrium and that changes in the amorphous and crystalline structure can occur with increasing temperature [36]. In addition, starting from $800{ }^{\circ} \mathrm{C}$, mass loss was evident and sharp in all adsorbents. This is particularly related to the decomposition and change of the carbon skeleton found in polymer-coated materials [37]

\subsubsection{DSC ANALYSIS}

DSC analysis results of magnetic materials obtained with various polymeric materials by using activated carbon samples are given in Fig 6.

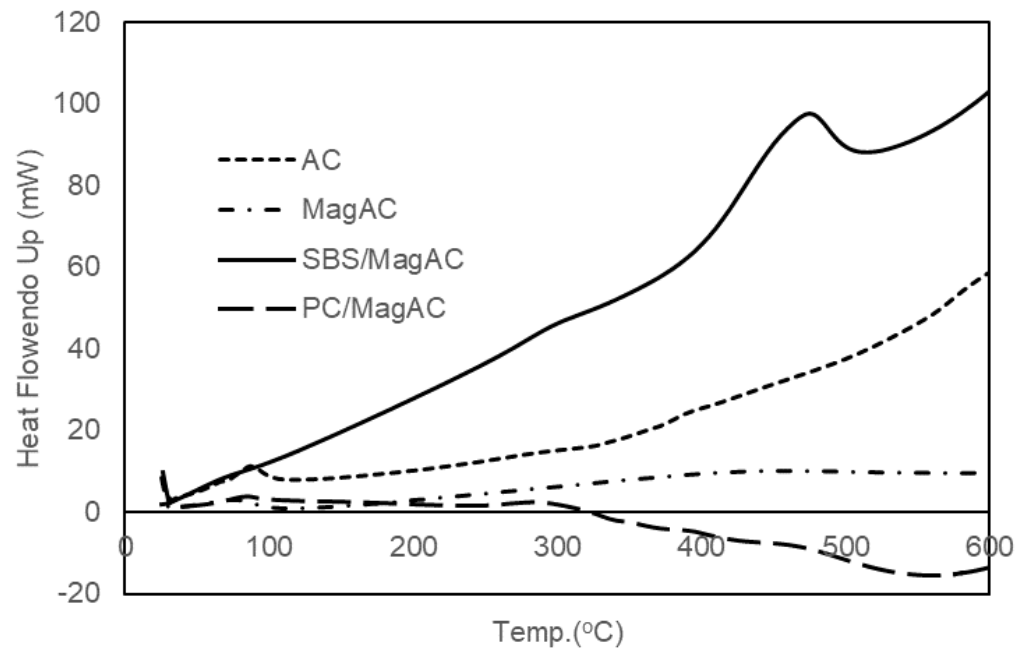

Figure 6: DSC results of AC, MagAC, SBS/MagAC and PC/MagAC adsorbents 
The most important applications of thermogravimetric methods are for polymers. The decomposition mechanisms of various polymeric materials can be explained by the information obtained from thermograms. In addition, the investigation behaviour characteristic of each type polymer is used in the identification of polymers. In the DSC process, the temperature of the sample and reference is increased at a regular rate by measuring the amount of energy absorbed or released while the sample is heated and cooled or maintained at a constant temperature. In endothermic reactions heat goes into the sample but in exothermic reactions heat flows out of the sample. The heat lost or recovered as a result of endothermic or exothermic reactions in the sample is recovered. Furthermore, the heating rate is recorded as a function of the sample temperature. When examined in Fig 6 it is seen that there are endothermic peaks around $100^{\circ} \mathrm{C}$ in AC samples. In MagAC sample, it is observed that one exothermic peak is formed and it is increased affected by temperature. Exothermic peaks at $500^{\circ} \mathrm{C}$ in SBS/MagAC samples exothermic peaks at $100^{\circ} \mathrm{C}$ and $300^{\circ} \mathrm{C}$ and endothermic peaks at PC/MagAC samples. In addition, it is seen that all the samples of temperature resistance are generally lower [37].

\subsubsection{FT-IR IMAGES}

FT-IR spectra of polymeric coated magnetic materials using activated carbon samples are given in Fig.7.
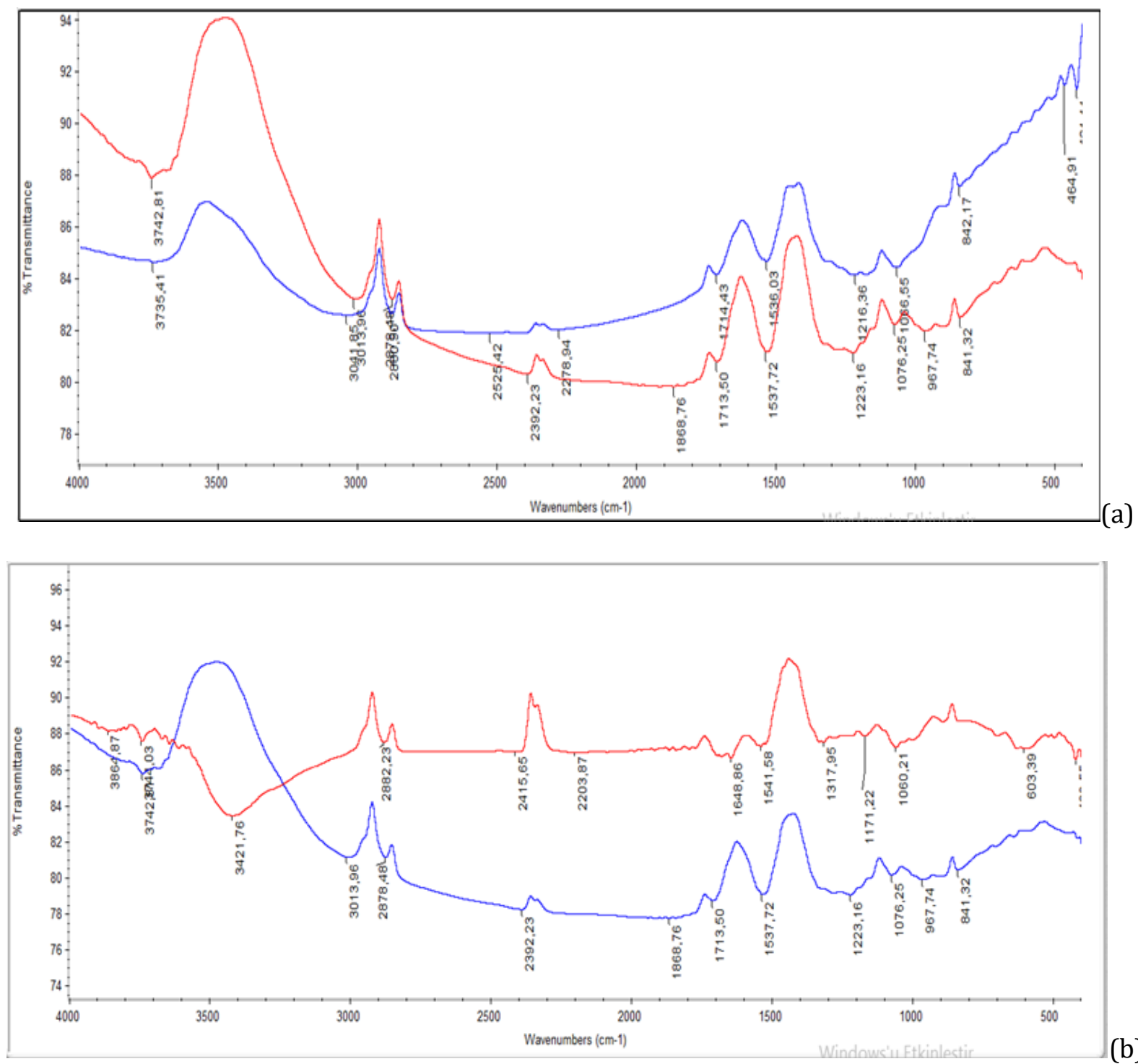
Mehmet Uğurlu, Huseyn Osman, Ali imran Vaizoğullar, and Abdul Chaudhary

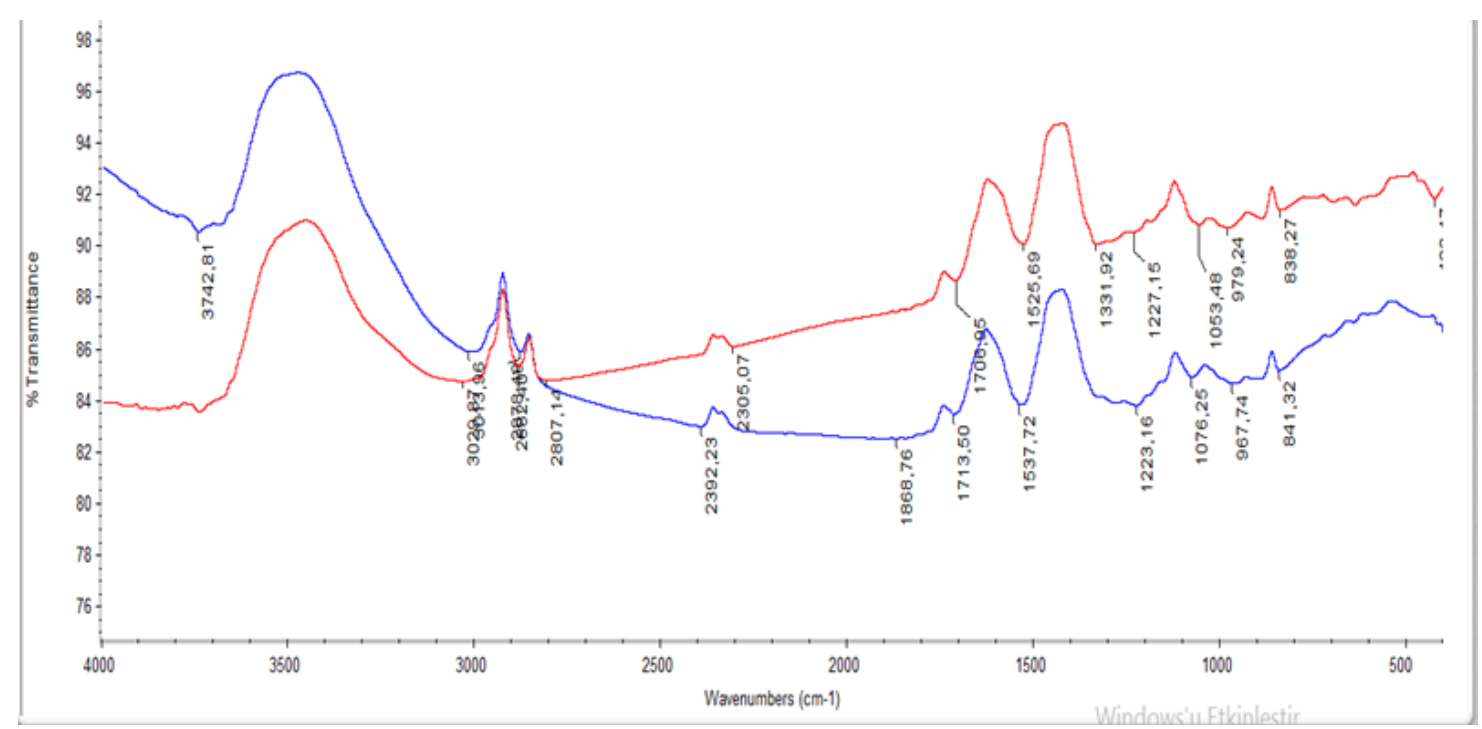

Figure 7: FT-IR results a) AC vs MagAC, b) AC vs PC/MagAC, c) AC vs SBS/MagAC adsorbents

1) When the FT-IR spectra of pure activated carbon were examined. it was observed that the peak of $-\mathrm{OH}$ group observed at $3041.85 \mathrm{~cm}-1$ shifted to $3013.96 \mathrm{~cm}^{-1}$ as a result of the interaction with $\mathrm{Fe}_{3} \mathrm{O}_{4}$ nanoparticles. Therefore, we can infer that adsorption occurs by physical interaction with $\mathrm{OH}$ groups on the surface. However, the $\mathrm{C}-\mathrm{O}$ single bond to which the $-\mathrm{OH}$ group is bound and observed at $1216.36 \mathrm{~cm}^{-}$ ${ }^{1}$ has been strengthened by the weakening of the $-\mathrm{OH}$ group and shifted to $1223.16 \mathrm{~cm}^{-1}$. This is another proof of the interaction of nanoparticles with this group. The peaks of the -CH group observed at 2880.90 $\mathrm{cm}-1$ of activated carbon in the free state were significant in the peaks of the $\mathrm{C}=0$ group observed at $1714.43 \mathrm{~cm}^{-1}$ and the $\mathrm{C}=\mathrm{C}$ tensile peaks at $1536.03 \mathrm{~cm}^{-1}$. the absence of a change indicates that there was no interaction with these groups.

2) When the FT-IR spectrum of the product obtained by the interaction of activated carbon coated with $\mathrm{Fe}_{2} \mathrm{Fe}_{3} \mathrm{O}_{4}$ nanoparticles with polycarbonate polymer. the $-\mathrm{OH}$ peak observed at $3019.96 \mathrm{~cm}^{-1}$ shifted to $3421.76 \mathrm{~cm}^{-1}$. This is due to the hydrogen bond between the -COO group and the $-\mathrm{OH}$ molecules in the structure during the bonding of polycarbonate to the MagAC composite material. Another proof of this is the $\mathrm{C}=0$ bond peak observed at $1648.86 \mathrm{~cm}-1$ in polycarbonate bonded MagAC composite material. This peak was weakened by hydrogen bond formation and appeared at $1648.86 \mathrm{~cm}-1$. Fe-C bonds not observed in MagAC composite material were observed at $603.39 \mathrm{~cm}-1$ in polycarbonate bonded MagAC composite material which explains the bond formed between the surface-coated $\mathrm{Fe}$ metal and polycarbonate polymer. C-O bond observed at $1223.16 \mathrm{~cm}-1$ in MagAC composite material weakened during the interaction between polycarbonate and MagAC composite material and appeared at 1171.22 $\mathrm{cm}^{-1}$.

3) When the IR spectrum of the product obtained by the interaction of $\mathrm{Fe}_{2} \mathrm{Fe}_{3} \mathrm{O}_{4}$ coated activated carbon with SBS polymer was observed. no change was observed in the spectrum [38], [39].

\subsection{ADSORPTION RESULTS}

Magnetic and polymer coated adsorbents were synthesized by using activated carbon (AC) as a base material. The process optmisation was done by investigating the effects of solid-liquid ratio, temperature, initial FLQ concentrations and solution $\mathrm{pH}$ values under identical experimental conditions. The variation of the adsorbed amount per gram weight of adsorbents over time was evaluated separately for each parameter.

\subsubsection{EFFECT OF SOLID-LIQUID RATIO}

To investigate the effect of solid/liquid ratio, the removal rates of FLQ using adsorbent materials were plotted in Fig. 8. 

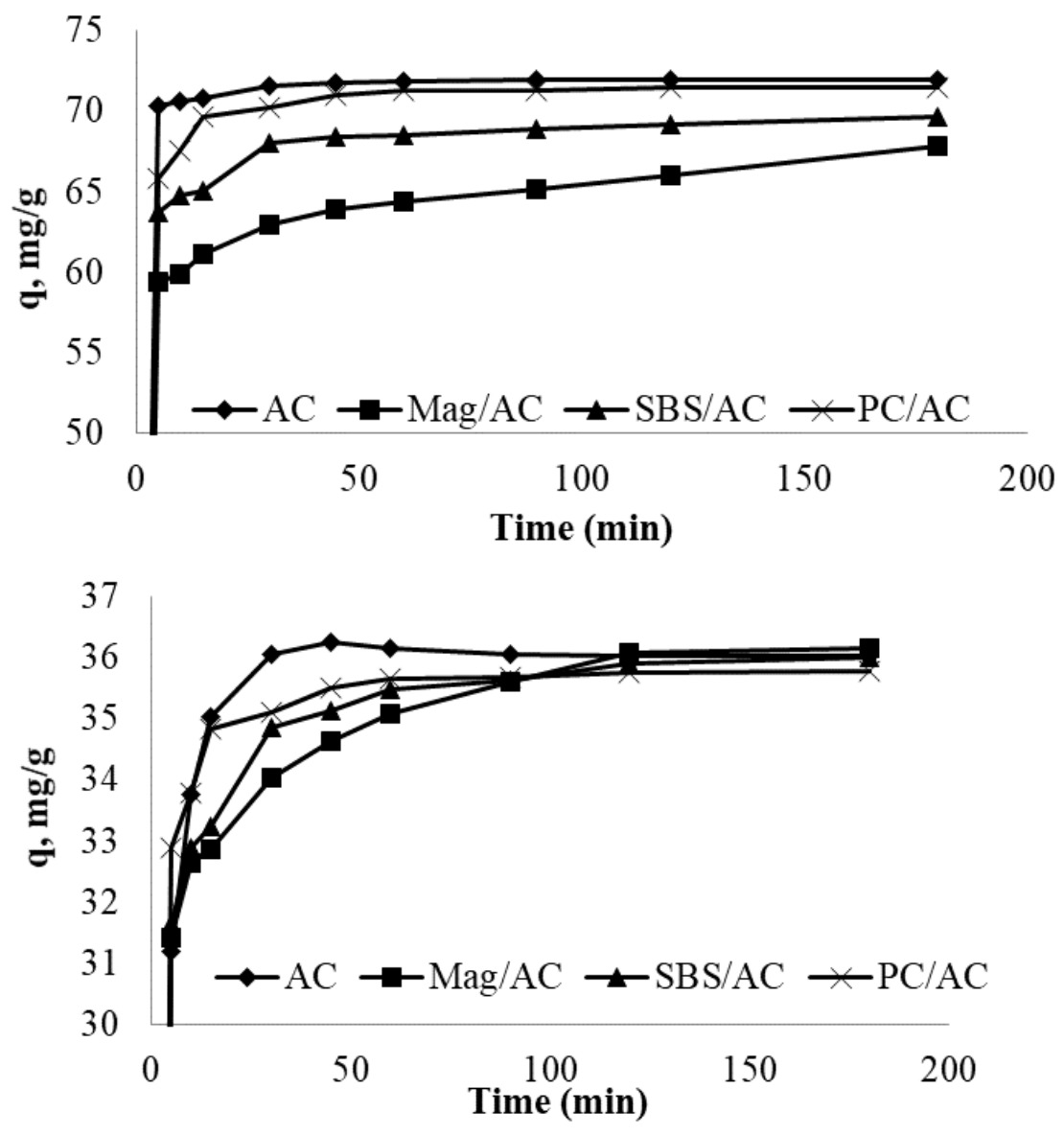

(a)

(b)

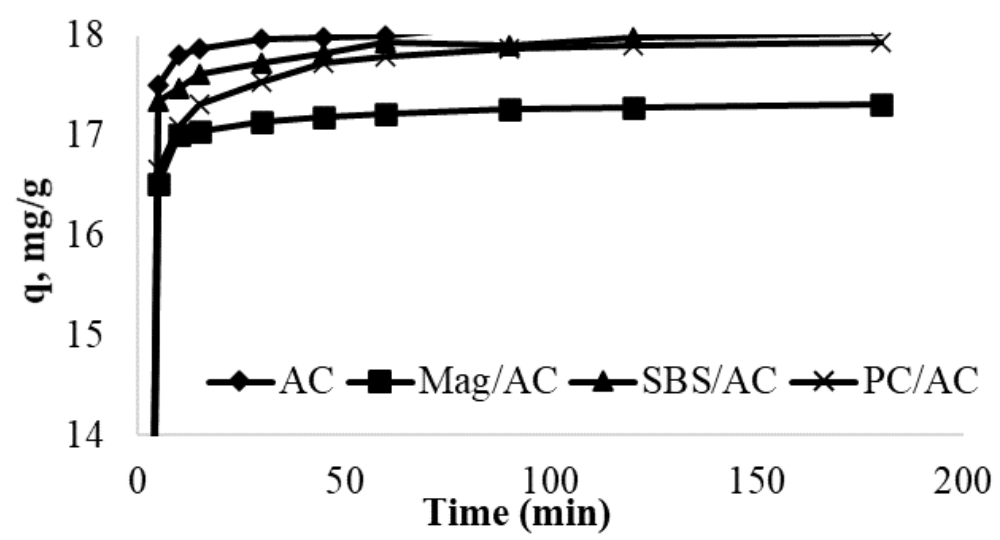

(c)

Figure 8: The amount of FLQ adsorbed over time in adsorption with different adsorbents $0.5 \mathrm{~g} / \mathrm{L} \mathrm{(a),} 1.0 \mathrm{~g} / \mathrm{L}$ (b), and $2.0 \mathrm{~g} / \mathrm{L}$ (c) Conditions: Temperature $=298 \mathrm{~K}$; natural pH ; FLQ conc., $=37 \mathrm{mg} / \mathrm{L}$; constant mixing )

The adsorbent dosage influences the total specific surface area of binding sites and thus is an important factor affecting adsorption [40]. Fig 8 shows that the removal efficiency of FLQ increased sinigicantly with an increase in adsorbents dosage.

However, due to the increase in all solid-liquid ratios, there is a significant reduction in the amount of adsorbed, while the amount of adsorbed per gram decreases as the amount of adsorbent increases. This situation is thought to arise from the interaction of the magnetic material in the solution and the properties of the adsorbent surface. In addition, although the adsorption performance is high at low concentration, low removal at the end point, the higher the adsorption rate per gram, the higher the amount of adsorbed substance per gram. The best results in terms of 
performance are seen in AC, PC/MagAC, SBS/MagAC and MagAC examples, respectively. In addition, since $1.0 \mathrm{~g} / \mathrm{L}$ adsorbent provided a significant increase in removal, subsequent experiments were conducted taking this solidliquid ratio into account. Table 2 compares the adsorption capacities for FLQ on different types of adsorbents reported in the literature. As can be seen, different adsorbents exhibit different adsorption capacities for adsorption which indicates that adsorbent's properties have a significant effect on its efficacy. The results show that the adsorption capacity of the mangnetice compounds used in this study is higher in most cases than reported in the literature.

Table 2: Literature results of the adsorption capacities of FQs onto different adsorbents

\begin{tabular}{|c|c|c|c|}
\hline Adsorbents & Adsorbates & $\begin{array}{l}\text { Adsorption capacity } \\
\qquad(\mathrm{mg} / \mathrm{g})\end{array}$ & References \\
\hline Bamboo Biochar & $\begin{array}{l}\text { Enrofloxacin } \\
\text { ofloxacin }\end{array}$ & $\begin{array}{l}45.88-46.90 \\
45.11-46.66\end{array}$ & [41] \\
\hline PPy-O-CGF & Enr, Cip, Nor & $83.06-90.67$ & [42] \\
\hline Aluminum and iron hydrous oxides & Cip & $13.58-21.87$ & {$[43]$} \\
\hline $\operatorname{Poly}(m$-phenylenediamine)-CGF & Cip & $64.9-77.3$ & [44] \\
\hline Tourmaline, halloysite, biotite & Cip & $3.31-21.7$ & [45] \\
\hline Titanium oxide nanoparticles & Ofl & $1.99-12.26$ & [46] \\
\hline $\begin{array}{c}\text { Corn stalks, reed stalks, willow branches- } \\
\text { biochar }\end{array}$ & Nor & $3.51-7.25$ & [47] \\
\hline Carboxylated multiwall Carbon nanotube & Nor & 70 & [48] \\
\hline Powdered activated carbon & $\begin{array}{l}\text { Nor, Cip, Lom, Sar, Enr, } \\
\text { Ofl }\end{array}$ & $93.5-190$ & [49] \\
\hline Magnetic chitosan graphene oxide composite & Cip & $30-38$ & {$[50]$} \\
\hline Activated carbon AC & FLQ & $19.10-73.47$ & This study \\
\hline Magnetic activated carbon (MagAC) & FLQ & $17.24-67.45$ & This study \\
\hline $\begin{array}{l}\text { Styrene-butadiene styrene magnetic AC } \\
\text { (SBS/MagAC) }\end{array}$ & FLQ & 18.62-69.11 & This study \\
\hline Poly charbon magnetic AC (PC/MagAC) & FLQ & $18.43-69.12$ & This study \\
\hline
\end{tabular}

\subsubsection{TEMPERATURE EFFECT}

Temperature is one of the most significant factors affecting the adsorption of micro-aqueous media and hance it was studied, considering three different temperature of $291 \mathrm{~K}, 298 \mathrm{~K}, 308 \mathrm{~K}$. The removal values of FLQ using different adsorbent materials are showed in Fig 9.

The data in Figure 9 showed that the adsorption rate increases in the first 5 minutes with the increase of temperature, and the system reaches equilibrium at the end of about 90 minutes. It was observed that the amount of material adsorbed at almost all temperatures reached equilibrium. When the data of all adsorbents were examined at $291 \mathrm{~K}$ temperature, the best performance was observed in AC (37 mg/g) and the lowest efficiency was observed in SBS/MagAC samples $(11 \mathrm{mg} / \mathrm{g})$. In the experimental study performed at room temperature, higher removal with AC was $37 \mathrm{mg} / \mathrm{g}$ and the lowest removal with MagAC was $35 \mathrm{mg} / \mathrm{g}$. At high temperature (308K), AC 
was provided with $38 \mathrm{mg} / \mathrm{g}$, again showing better results, while the lowest rate was observed in SBS/MagAC (16 $\mathrm{mg} / \mathrm{g})$. This situation can be explained by the decrease in adsorption with the decrease in temperature exothermically after a slight increase due to the decrease in viscosity with the increase in temperature [51].
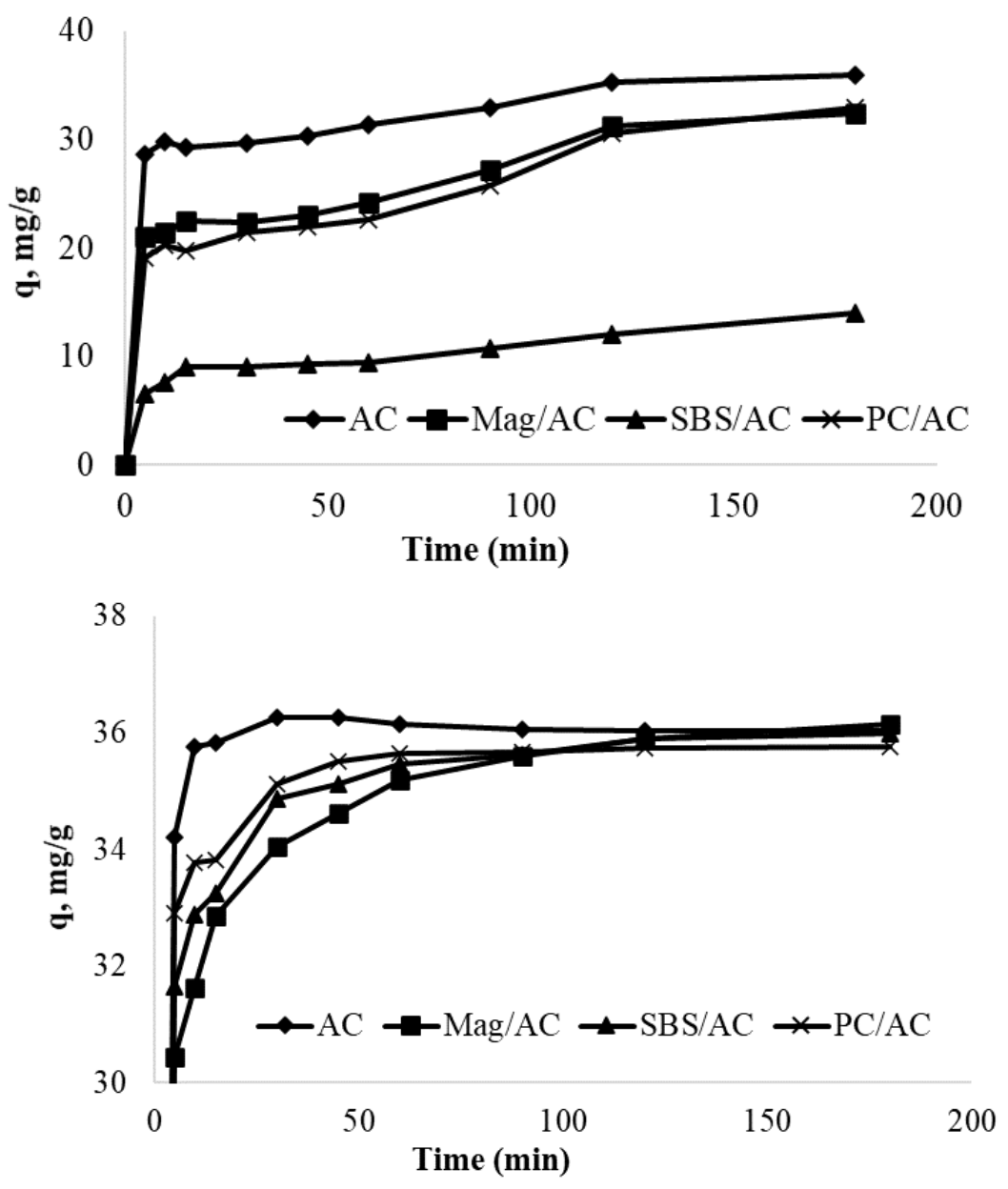

(a)

(b)

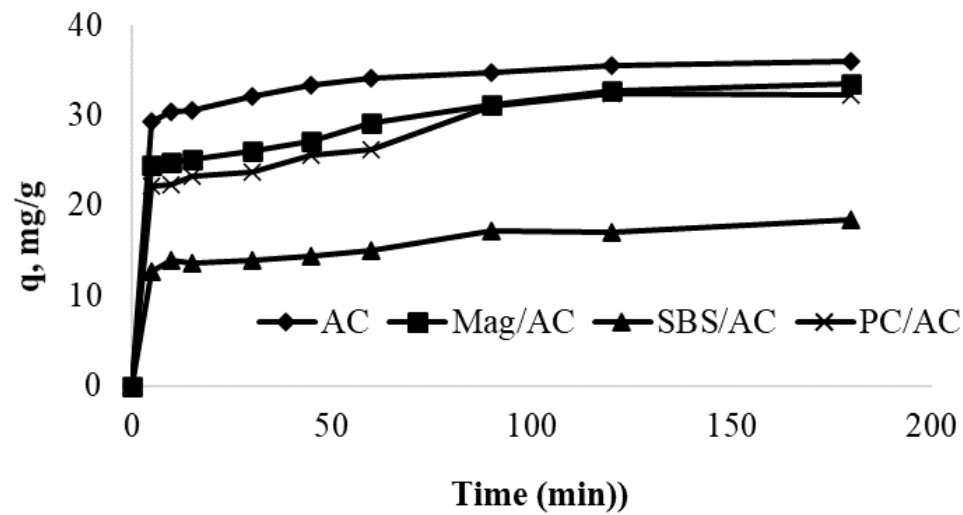

Figure 9: The amount of FLQ adsorbed over time at different temperatures (291 K (a), $298 \mathrm{~K}$ (b), $308 \mathrm{~K}$ (c) (1.0 g / $\mathrm{L}$, natural $\mathrm{pH}$, constant mixing speed, 37ppm)) 


\subsubsection{THE EFFECT OF INITIAL CONCENTRATION}

To examine the initial concentration effect, changes in the amount of FLQ adsorbed per gram using adsorbent materials are plotted in Fig. 10.

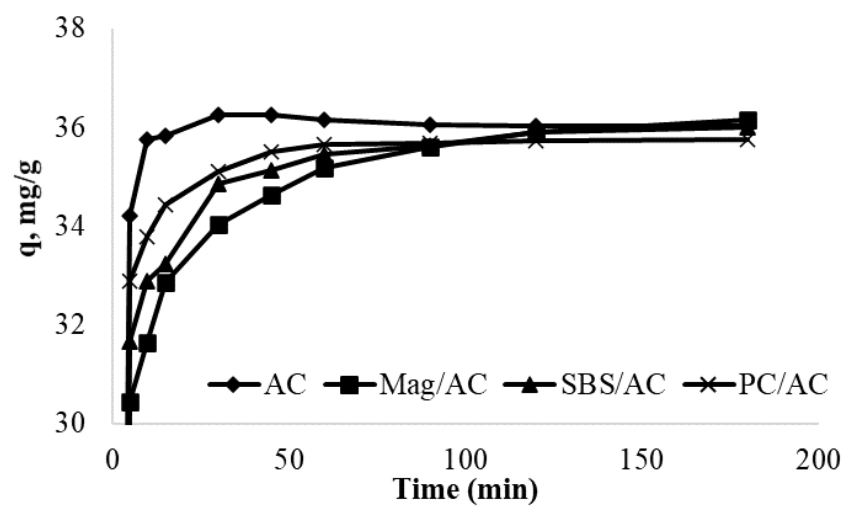

(a)

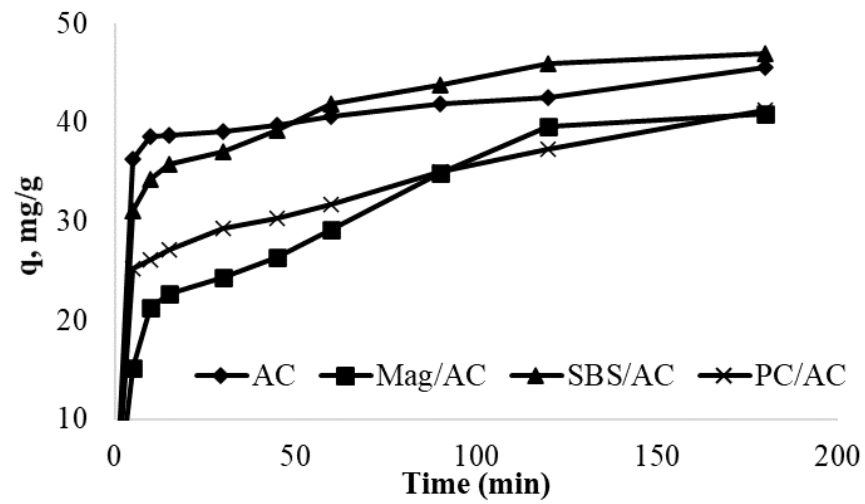

(b)

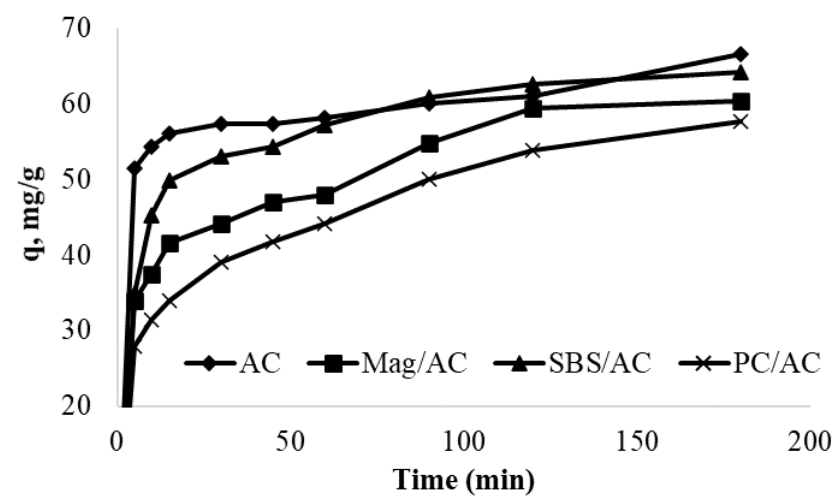

(c)

Figure 10: The amount of FLQ adsorbed over time in adsorption at different concentrations $37 \mathrm{mg} / \mathrm{L}(\mathrm{a}), 60$ $\mathrm{mg} / \mathrm{L}(\mathrm{b}), 100 \mathrm{mg} / \mathrm{L}$ (c) (1.0 g/L, $298 \mathrm{~K}$, natural pH, constant mixing speed)

The data in Figure 10 showed that, under identical experimental conditions, the adsorption efficiency increases with increasing the initial concentration of FLQ. It is seen that in the first 5 minutes a rapid adsorption occurs at all initial concentrations and equilibrium is reached in almost all species. In addition, it is observed that more pronounced and superior adsorption performance is obtained in AC and SBS/MagAC adsorbent samples. In addition, the adsorption rate is low with high concentration of PC/MagAC. In general, the \% yield value decreased although the amount of FLQ adsorbed increased when the initial concentrations were increased. In addition, The adsorption reaching equilibrium in a short time can be associated with the physical character of the interaction [52]. 


\subsubsection{THE EFFECT OF PH}

In order to investigate the effect of $\mathrm{pH}$, the changes that occur in the adsorption capacity of FLQ using AC and other synthesized magnetic adsorbents are given in Fig.11.

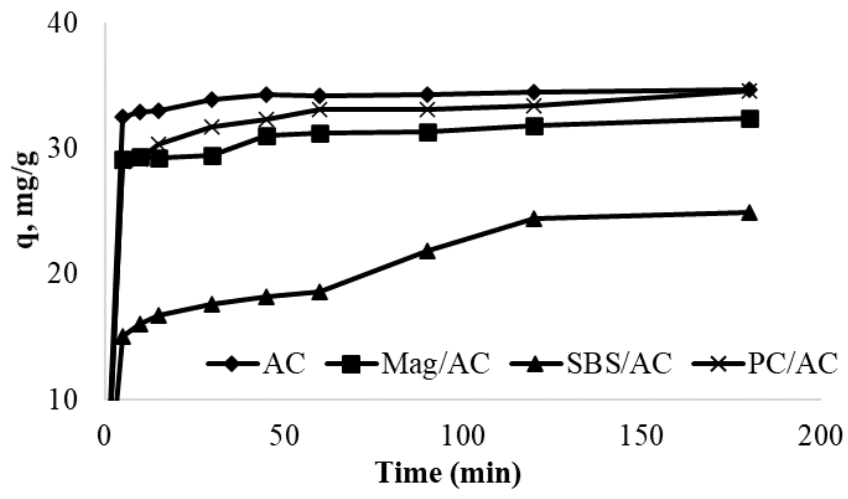

(a)

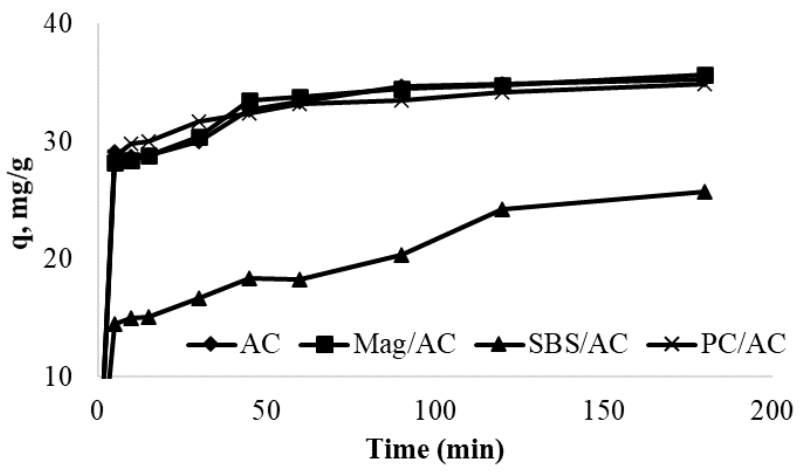

(b)
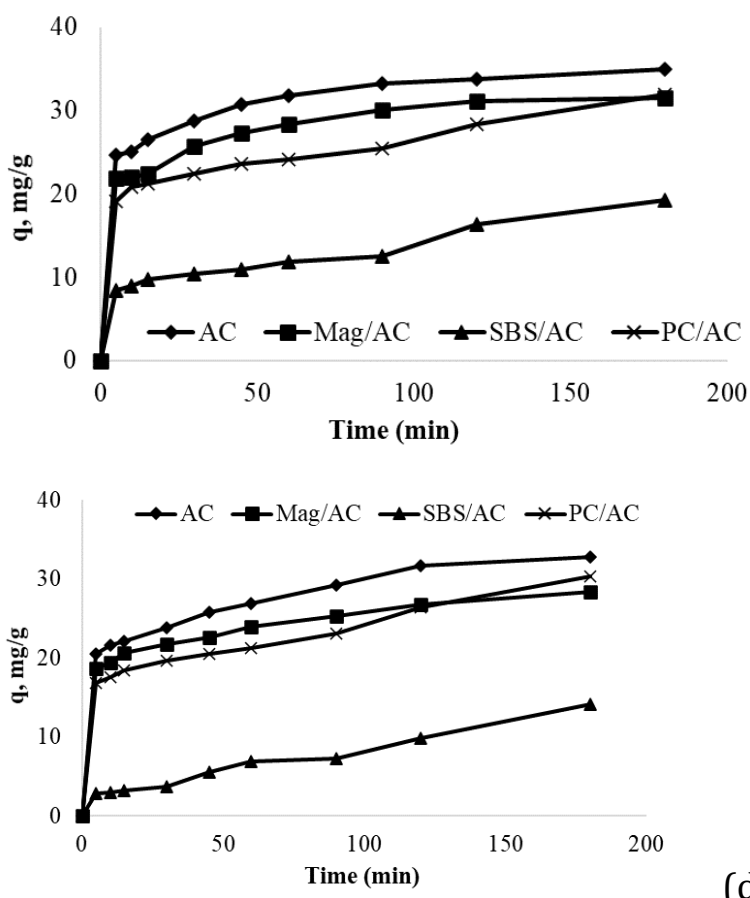

(c)

Figure 11: The amount of FLQ adsorbed per gram of adsorbent depending on the pH effect pH:3.0 (a), pH:5.0 b), pH:7.0 (c), pH 9 (d) $(1.0$ g/L, 298K, $37 \mathrm{mg} / \mathrm{L}$, constant mixing speed) 
The data in Fig. 11 showed that the removal efficiency decreased as the solution pH increased from 3 to 9. In the adsorption with all adsorbents, it was determined that the same behaviors were observed in the adsorbents at low $\mathrm{pH}$ values except SBS/MagAC. Here, values of $37 \mathrm{mg} / \mathrm{L}$ were obtained in both $\mathrm{pH}$ ranges. It was observed that in neutral $\mathrm{pH}$ values, respectively, AC, MagAC, PC/MagAC and lowest SBS/MagAC values. When the chemical structure of FLQ is examined, it is thought that it can be significantly affected by the $\mathrm{pH}$ change, since it has different functional groups and its solubility is higher in the basic environment. Considering these features, it is estimated that adsorption to different adsorbents may occur at different $\mathrm{pH}$ 's.

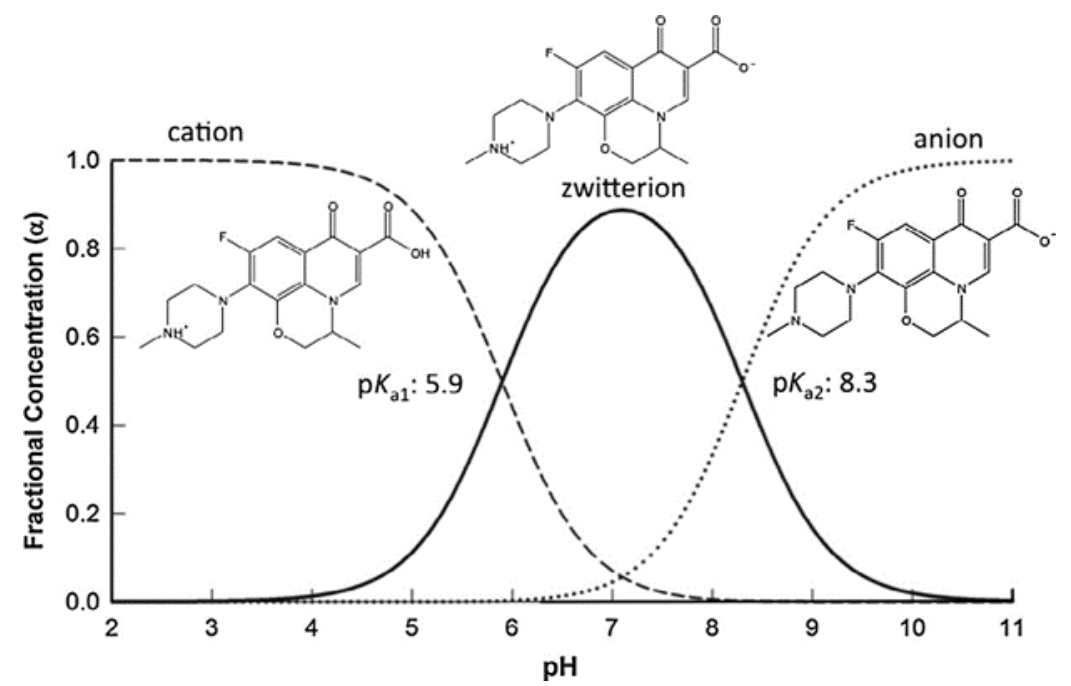

Figure 12: Aqueous phase acid-base speciation of OFX, highlighting the predominance of the zwitterionic species at $\mathrm{pKa} 1<\mathrm{pH}<\mathrm{pKa} 2$.

It have been reported flumequine $\mathrm{pK}_{\mathrm{a}}$ values of acidic [53]. So, it seems to exhibit weakly acid properties for its carboxylic group and lacks of a piperazine ring [54]. This originates from two phenomena: (i) flumequine was negatively charged above $\mathrm{pH} 6.5\left(\mathrm{pK}_{\mathrm{a}}=6.2\right)$ [55] and (ii) the adsorbents surface carried more negative charges with increasing $\mathrm{pH}$. These two phenomena led to electrostatic repulsions, which implies that variable charges are implicated in the sorption mechanism. A similar trend was observed for fluoroquinolones sorption onto soil constituents or whole soils [55]. Gu et al. [56] showed that ciprofloxacin sorption onto iron and aluminum hydrous oxides was highly $\mathrm{pH}$ dependent in the 4-10 range and followed the species distribution of the antibiotic. Therefore, the neutral form of flumequine dominates at $\mathrm{pH}<\mathrm{pK}_{\mathrm{a}}$ and the anionic form is mainly present at $\mathrm{pH}>\mathrm{pK}$. Since, at $\mathrm{pH} .<\mathrm{pH}$ PZC AC surface was determined been positively charged and the reverse for $\mathrm{pH}$ values $>\mathrm{pH}$ Pzc. Adsorption seems to decreased after at these $\mathrm{pH}$ ranges, which is near the reported $\mathrm{pK}_{\mathrm{a}}$ values of FLQ (Fig. 12). In other words, The typical environmental pH of antibiotic water environment (weakly acidic) was favorable for FLQ adsorption [57].

\section{Adsorption Isotherms}

Adsorption isotherms data were essential to understand the interaction between adsorbate and adsorbent surface sites. The equilibrium time and adsorption isotherm obtained for the FLQ -adsorbents system are depicted in Table 3. Herein, the adsorption behavior of FLQ onto adsorbents were evaluated by the most frequently used isotherm models. Monolayer surface coverage and the equal availability of adsorption sites and no transmigration of adsorbates in the plane of the surface are the idealized assumptions associated with the Langmuir adsorption model [58]. On the other hand, the Freundlich isotherm is an empirical model that assumes the presence of the interaction between the molecules of the adsorbate, all surface sites are different and the multilayer adsorption [59]. Obviously, it is apparent from the results reported in Table 3 that the adsorption of FLQ onto adsorbents at all temperatures is well described by the Langmuir isotherm model ( $\mathrm{R}^{2}$ value of 0.95$)$. The goodness of Langmuir model suggests monolayer adsorption of FLQ at the outer surface of adsorbnets at all temperatures [60]. Thus, comparison of the $\mathrm{R}^{2}$ values for both models (Table 3) showed that adsorption of the mixed pollution by all adsorbents were more consistent with the Langmuir adsorption model. This indicated that monolayer adsorption of FLQ on to the surface of adsorbents were significant and most likely the dominant mechanism. 
Table 3: Freundlich and Langmuire values for AC, Mag AC, SBS/MagAC and PC/Mag AC Adsorption kinetics

\begin{tabular}{|c|c|c|c|c|c|c|}
\hline \multirow{2}{*}{ Adsorbents } & \multicolumn{3}{|c|}{ Freundlich } & \multicolumn{3}{c|}{ Langmuire } \\
\cline { 2 - 7 } & $\mathrm{n}$ & $\mathrm{K}_{\mathrm{f}}$ & $\mathrm{R}^{2}$ & $\mathrm{bx} 10^{-2}$ & $\mathrm{Q}_{\mathrm{o}}$ & $\mathrm{R}^{2}$ \\
\hline AC & 6,565 & 35,12 & 0,82 & 28,98 & 70,42 & 0,95 \\
\hline MagAC & 9,487 & 35,58 & 0,65 & 26,51 & 61,72 & 0,98 \\
\hline SBS/MagAC & 6,631 & 34,12 & 0,91 & 35,83 & 67,56 & 0,98 \\
\hline PC/MagAC & 8,787 & 34,15 & 0,74 & 27,09 & 59,52 & 0,96 \\
\hline
\end{tabular}

Adsorption kinetic data is very useful in understanding the general mechanism associated with the adsorption of FLQ to all adsorbents. To investigate the kinetics of FLQ adsorption process in all adsorbents, three kinetic models were used (ie, pseudo first order, pseudo second order and intraparticle diffusion kinetic models). Graphics were placed using linear regression and kinetic parameters are shown in Tables $4 \mathrm{a}$ and $4 \mathrm{~b}$.

It was observed that FLQ adsorption to all adsorbents followed the pseudo-second reaction with high correlation coefficients $\left(\mathrm{R}^{2}: 0.94-1.00\right)$ generally and the adsorption capacity (qe, cal) from the pseudo-second-order model was much closer to experimental experience. data indicating that the process controlling the speed may be a chemical sorption (qe, exp) [54]. These observations were consistent with sorption mechanisms that suggested strong electrostatic interaction or ion exchange on the absorbent surface. In this case, the adsorption process of FLQ can be defined as chemisorption and it is suggested that the rate determination step is surface adsorption [61], [62].

As the initial concentration of the FLQ solution changes from $37 \mathrm{mg} / \mathrm{L}$ to $100 \mathrm{mg} / \mathrm{L}$, the second order rate constants $\left(\mathrm{k}_{2}\right)$ of the adsorption reaction where the adsorbed amount appears increasingly different for each adsorbent (Tables $4 \mathrm{a}$ and $4 \mathrm{~b}$ ). Two dominant factors have been proposed: (i) an increase in the initial FLQ concentration may increase the driving force of the concentration gradient between the adsorbent in the solution and the adsorbent in the solution, and may result in higher FLQ intake, and (ii) higher concentrations of adsorbate molecules were greater for the active regions [63]. In addition, the appropriateness of the particle diffusion model was examined in the presented study. Here, $\mathrm{R}^{2}$ value was observed to be significant. Given the intraparticle diffusion model, it can be said that there is a close agreement between the experimental and theoretical qe value, which confirms the applicability of this model by all adsorbents to explain phenol adsorption. This means that surface adsorption and intraparticle diffusion occur simultaneously. This can be attributed primarily to the outer surface of the adsorbents in two stages, and then one by diffusion into the pores [64].

Table 4a: In FLQ adsorption of AC and Mag AC and I. II. degree kinetic model and particle diffusion data

\begin{tabular}{|c|c|c|c|c|c|c|c|c|c|c|c|c|c|c|c|c|c|c|}
\hline \multirow{3}{*}{ 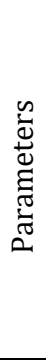 } & & \multicolumn{8}{|c|}{$\mathrm{AC}$} & \multicolumn{9}{|c|}{ MagAC } \\
\hline & \multirow{2}{*}{$\begin{array}{c}\text { First } \\
- \\
\text { orde } \\
r \\
\mathrm{R}^{2}\end{array}$} & \multicolumn{4}{|c|}{ Pseudo-second-order } & \multicolumn{4}{|c|}{ Intra-particle diffusion } & \multirow{2}{*}{$\begin{array}{c}\text { First } \\
- \\
\text { orde } \\
r \\
\end{array}$} & \multicolumn{4}{|c|}{ Pseudo-second-order } & \multicolumn{4}{|c|}{ Intra-particle diffusion } \\
\hline & & 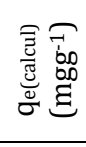 & 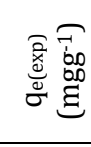 & ્ָથ & $\approx$ & ज્વ & $\cup$ & $\approx$ & $\underset{\Xi}{\curvearrowright} . \Xi$ & & 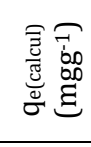 & 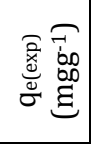 & ఇָ & $\approx$ & 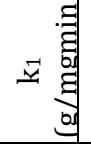 & $\cup$ & $\approx$ & $\underset{\Xi}{ } . \Xi$ \\
\hline \multicolumn{19}{|c|}{ Ads. dos. $\left(\mathrm{gL}^{-1}\right)$} \\
\hline 0,5 & 0,93 & $\begin{array}{c}71,9 \\
4 \\
\end{array}$ & $\begin{array}{c}71,9 \\
9 \\
\end{array}$ & 0,07 & $\begin{array}{c}1,0 \\
0 \\
\end{array}$ & 0,15 & $\begin{array}{c}70,3 \\
4 \\
\end{array}$ & $\begin{array}{c}0,7 \\
6 \\
\end{array}$ & 0,20 & 0,96 & $\begin{array}{c}68,0 \\
2 \\
\end{array}$ & $\begin{array}{c}67,8 \\
7 \\
\end{array}$ & $\begin{array}{c}0,00 \\
6 \\
\end{array}$ & $\begin{array}{c}0,9 \\
9\end{array}$ & $\begin{array}{c}0,7 \\
4\end{array}$ & $\begin{array}{c}58,1 \\
9\end{array}$ & $\begin{array}{c}0,9 \\
7\end{array}$ & 2,46 \\
\hline 1,0 & 0,90 & $\begin{array}{c}36,1 \\
0 \\
\end{array}$ & $\begin{array}{c}36,0 \\
2 \\
\end{array}$ & 3,86 & $\begin{array}{c}1,0 \\
0 \\
\end{array}$ & $\begin{array}{c}0, .06 \\
8 \\
\end{array}$ & $\begin{array}{c}35,2 \\
1 \\
\end{array}$ & $\begin{array}{c}0,3 \\
5 \\
\end{array}$ & 0,01 & 0,84 & $\begin{array}{c}36,2 \\
3 \\
\end{array}$ & $\begin{array}{c}36,1 \\
5 \\
\end{array}$ & $\begin{array}{c}0,01 \\
7 \\
\end{array}$ & $\begin{array}{c}0,9 \\
9 \\
\end{array}$ & $\begin{array}{c}0,3 \\
9 \\
\end{array}$ & $\begin{array}{c}31,4 \\
3 \\
\end{array}$ & $\begin{array}{c}0,8 \\
8 \\
\end{array}$ & 1,63 \\
\hline 2,0 & 0,91 & $\begin{array}{c}18,1 \\
8 \\
\end{array}$ & $\begin{array}{c}18,1 \\
7 \\
\end{array}$ & 0,15 & $\begin{array}{c}1,0 \\
0 \\
\end{array}$ & $\begin{array}{c}0,04 \\
8 \\
\end{array}$ & $\begin{array}{c}17,6 \\
0 \\
\end{array}$ & $\begin{array}{c}0,7 \\
9 \\
\end{array}$ & 0,37 & 0,95 & $\begin{array}{c}17,3 \\
3\end{array}$ & $\begin{array}{c}17,3 \\
1\end{array}$ & 0,19 & $\begin{array}{c}1,0 \\
0\end{array}$ & $\begin{array}{c}0,0 \\
5\end{array}$ & $\begin{array}{c}16,7 \\
5\end{array}$ & $\begin{array}{c}0,6 \\
1\end{array}$ & 0,30 \\
\hline \multicolumn{19}{|c|}{ Temp. (K) } \\
\hline $\begin{array}{c}29 \\
1 \\
\end{array}$ & 0,92 & $\begin{array}{c}36,3 \\
6 \\
\end{array}$ & $\begin{array}{c}35,9 \\
2\end{array}$ & $\begin{array}{c}0,00 \\
5 \\
\end{array}$ & $\begin{array}{c}0,9 \\
9\end{array}$ & 0,68 & $\begin{array}{c}26,6 \\
9\end{array}$ & $\begin{array}{c}0,9 \\
2\end{array}$ & 5,57 & 0,95 & $\begin{array}{c}34,3 \\
6 \\
\end{array}$ & $\begin{array}{c}32,4 \\
3\end{array}$ & $\begin{array}{c}0,00 \\
2\end{array}$ & $\begin{array}{c}0,9 \\
9 \\
\end{array}$ & $\begin{array}{c}1,0 \\
4\end{array}$ & $\begin{array}{c}17,5 \\
4\end{array}$ & $\begin{array}{c}0,8 \\
6 \\
\end{array}$ & $\begin{array}{c}15,4 \\
2\end{array}$ \\
\hline $\begin{array}{c}29 \\
8 \\
\end{array}$ & 0,84 & $\begin{array}{c}36,1 \\
0\end{array}$ & $\begin{array}{c}36,0 \\
2\end{array}$ & 3,86 & $\begin{array}{c}0,9 \\
9\end{array}$ & 0,18 & $\begin{array}{c}35,1 \\
2 \\
\end{array}$ & $\begin{array}{c}0,6 \\
9\end{array}$ & 0,01 & 0,98 & $\begin{array}{c}36,3 \\
6 \\
\end{array}$ & $\begin{array}{c}36,1 \\
5 \\
\end{array}$ & $\begin{array}{c}0,01 \\
5\end{array}$ & $\begin{array}{c}0,9 \\
9\end{array}$ & $\begin{array}{c}0,4 \\
9\end{array}$ & $\begin{array}{c}30,6 \\
0\end{array}$ & $\begin{array}{c}0,8 \\
4\end{array}$ & 1,84 \\
\hline $\begin{array}{c}30 \\
8 \\
\end{array}$ & 0,99 & $\begin{array}{c}36,2 \\
3 \\
\end{array}$ & $\begin{array}{c}35,9 \\
2 \\
\end{array}$ & $\begin{array}{c}0,00 \\
9 \\
\end{array}$ & $\begin{array}{c}1,0 \\
0 \\
\end{array}$ & 0,62 & $\begin{array}{c}28,5 \\
4 \\
\end{array}$ & $\begin{array}{c}0,9 \\
4 \\
\end{array}$ & 3,09 & 0,95 & $\begin{array}{c}33,0 \\
0 \\
\end{array}$ & $\begin{array}{c}33,5 \\
4 \\
\end{array}$ & $\begin{array}{c}0,00 \\
4 \\
\end{array}$ & $\begin{array}{c}0,9 \\
7 \\
\end{array}$ & $\begin{array}{c}0,9 \\
0 \\
\end{array}$ & $\begin{array}{c}21,6 \\
9 \\
\end{array}$ & $\begin{array}{c}0,9 \\
3 \\
\end{array}$ & 7,45 \\
\hline \multicolumn{19}{|c|}{ Initial Con.(mgL-1) } \\
\hline
\end{tabular}


Mehmet Uğurlu, Huseyn Osman, Ali imran Vaizoğullar, and Abdul Chaudhary

\begin{tabular}{|c|c|c|c|c|c|c|c|c|c|c|c|c|c|c|c|c|c|c|}
\hline 37 & 0,84 & $\begin{array}{c}36,1 \\
0\end{array}$ & $\begin{array}{c}36,0 \\
2\end{array}$ & 3,86 & $\begin{array}{c}0,9 \\
9\end{array}$ & 0,09 & $\begin{array}{c}35,2 \\
1\end{array}$ & $\begin{array}{c}0,3 \\
5\end{array}$ & 0,01 & 0,98 & $\begin{array}{c}36,1 \\
0\end{array}$ & $\begin{array}{c}36,1 \\
5\end{array}$ & $\begin{array}{c}0,01 \\
5\end{array}$ & $\begin{array}{c}0,9 \\
9\end{array}$ & $\begin{array}{c}0,4 \\
9\end{array}$ & $\begin{array}{c}30,6 \\
0\end{array}$ & $\begin{array}{c}0,8 \\
4\end{array}$ & 1,84 \\
\hline 60 & 0,91 & $\begin{array}{c}45,2 \\
4\end{array}$ & $\begin{array}{c}45,5 \\
3\end{array}$ & $\begin{array}{c}0,00 \\
5\end{array}$ & $\begin{array}{c}0,9 \\
9\end{array}$ & 0,69 & $\begin{array}{c}35,3 \\
8\end{array}$ & $\begin{array}{c}0,9 \\
2\end{array}$ & 4,39 & 0,91 & $\begin{array}{c}36,3 \\
6\end{array}$ & $\begin{array}{c}40,8 \\
7\end{array}$ & $\begin{array}{c}0,00 \\
1\end{array}$ & $\begin{array}{c}0,9 \\
6\end{array}$ & $\begin{array}{c}2,2 \\
4\end{array}$ & $\begin{array}{c}12,1 \\
2\end{array}$ & $\begin{array}{c}0,9 \\
3\end{array}$ & $\begin{array}{c}24,4 \\
7\end{array}$ \\
\hline $\begin{array}{c}10 \\
0 \\
\end{array}$ & 0,92 & $\begin{array}{c}65,7 \\
8 \\
\end{array}$ & $\begin{array}{c}66,4 \\
8 \\
\end{array}$ & $\begin{array}{c}0,00 \\
3 \\
\end{array}$ & $\begin{array}{c}1,0 \\
0 \\
\end{array}$ & 1,09 & $\begin{array}{c}50,3 \\
3\end{array}$ & $\begin{array}{c}0,9 \\
0\end{array}$ & 5,01 & 0,95 & $\begin{array}{c}62,8 \\
9 \\
\end{array}$ & $\begin{array}{c}60,3 \\
5 \\
\end{array}$ & $\begin{array}{c}0,00 \\
1 \\
\end{array}$ & $\begin{array}{c}09 \\
9 \\
\end{array}$ & $\begin{array}{c}2,4 \\
2\end{array}$ & $\begin{array}{c}30,3 \\
9\end{array}$ & $\begin{array}{c}0,9 \\
6\end{array}$ & $\begin{array}{c}16,5 \\
7 \\
\end{array}$ \\
\hline \multicolumn{19}{|c|}{ Initial $\mathrm{pH}$} \\
\hline 3,0 & 0,95 & $\begin{array}{c}34,7 \\
2\end{array}$ & $\begin{array}{c}34,6 \\
5\end{array}$ & $\begin{array}{c}0,03 \\
4\end{array}$ & $\begin{array}{c}0,9 \\
9\end{array}$ & 0,20 & $\begin{array}{c}32,2 \\
6\end{array}$ & $\begin{array}{c}0,8 \\
3\end{array}$ & 0,85 & 0,85 & $\begin{array}{c}32,5 \\
7\end{array}$ & $\begin{array}{c}32,4 \\
7\end{array}$ & $\begin{array}{c}0,01 \\
9\end{array}$ & $\begin{array}{c}0,9 \\
9\end{array}$ & $\begin{array}{c}0,3 \\
3\end{array}$ & $\begin{array}{c}28,4 \\
2\end{array}$ & $\begin{array}{c}0,7 \\
7\end{array}$ & 1,62 \\
\hline 5,0 & 0,97 & $\begin{array}{c}35,8 \\
4 \\
\end{array}$ & $\begin{array}{c}35,3 \\
0\end{array}$ & $\begin{array}{c}0,00 \\
8 \\
\end{array}$ & $\begin{array}{c}0,9 \\
9\end{array}$ & 0,70 & $\begin{array}{c}27,0 \\
5 \\
\end{array}$ & $\begin{array}{c}0,8 \\
9 \\
\end{array}$ & 3,54 & 0,97 & $\begin{array}{c}36,1 \\
0\end{array}$ & $\begin{array}{c}35,6 \\
5 \\
\end{array}$ & $\begin{array}{c}0,00 \\
8 \\
\end{array}$ & $\begin{array}{c}0,9 \\
9 \\
\end{array}$ & $\begin{array}{c}0,7 \\
5\end{array}$ & $\begin{array}{c}26,7 \\
4 \\
\end{array}$ & $\begin{array}{c}0,8 \\
9 \\
\end{array}$ & 3,51 \\
\hline 7,0 & 0,97 & $\begin{array}{c}35,7 \\
1\end{array}$ & $\begin{array}{c}35,0 \\
1\end{array}$ & $\begin{array}{c}0,00 \\
4\end{array}$ & $\begin{array}{c}0,9 \\
9\end{array}$ & 1,01 & $\begin{array}{c}22,7 \\
0\end{array}$ & $\begin{array}{c}0,9 \\
2\end{array}$ & 7,14 & 0,97 & $\begin{array}{c}32,5 \\
7\end{array}$ & $\begin{array}{c}31,5 \\
6\end{array}$ & $\begin{array}{c}0,00 \\
4\end{array}$ & $\begin{array}{c}0,9 \\
9\end{array}$ & $\begin{array}{c}1,0 \\
3\end{array}$ & $\begin{array}{c}19,2 \\
3\end{array}$ & $\begin{array}{c}0,9 \\
3\end{array}$ & 7,92 \\
\hline 9,0 & 0,97 & $\begin{array}{c}34,6 \\
0\end{array}$ & $\begin{array}{c}33,8 \\
0\end{array}$ & $\begin{array}{c}0,00 \\
2\end{array}$ & $\begin{array}{c}0,9 \\
4\end{array}$ & 1,24 & $\begin{array}{c}17,3 \\
5\end{array}$ & $\begin{array}{c}0,9 \\
8\end{array}$ & $\begin{array}{c}14,7 \\
9 \\
\end{array}$ & 0,98 & $\begin{array}{c}31,3 \\
4\end{array}$ & $\begin{array}{c}31,3 \\
6\end{array}$ & $\begin{array}{c}0,00 \\
2\end{array}$ & $\begin{array}{c}0,9 \\
8\end{array}$ & $\begin{array}{c}1,1 \\
0\end{array}$ & $\begin{array}{c}15,4 \\
2\end{array}$ & $\begin{array}{c}0,9 \\
5\end{array}$ & $\begin{array}{c}15,9 \\
4\end{array}$ \\
\hline
\end{tabular}

Table 4b: In FLQ adsorption of SBS/MagAC and PC/MagAC and I. II. degree kinetic model and particle diffusion data

\begin{tabular}{|c|c|c|c|c|c|c|c|c|c|c|c|c|c|c|c|c|c|c|}
\hline \multirow{3}{*}{ 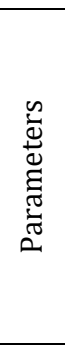 } & \multicolumn{9}{|c|}{ SBS/MagAC } & \multicolumn{9}{|c|}{ PC/MagAC } \\
\hline & \multirow{2}{*}{$\begin{array}{c}\text { Firs } \\
\mathrm{t}- \\
\text { ord } \\
\text { er } \\
\mathrm{R}^{2}\end{array}$} & \multicolumn{4}{|c|}{ Pseudo-second-order } & \multicolumn{4}{|c|}{ Intra-particle diffusion } & \multirow{2}{*}{$\begin{array}{c}\text { Firs } \\
\mathrm{t}- \\
\text { ord } \\
\text { er } \\
\mathrm{R}^{2}\end{array}$} & \multicolumn{4}{|c|}{ Pseudo-second-order } & \multicolumn{3}{|c|}{$\begin{array}{l}\text { Intra-particle } \\
\text { diffusion }\end{array}$} & \multirow{2}{*}{$\begin{array}{c} \\
\\
\mathrm{t}_{1 / 2} \\
(\mathrm{mi} \\
\mathrm{n})\end{array}$} \\
\hline & & $\begin{array}{l}\text { qe(calc } \\
\text { ul) } \\
\text { (mgg } \\
-1 \text { ) }\end{array}$ & $\begin{array}{c}\mathrm{q}_{\mathrm{e}(\mathrm{ex}} \\
\mathrm{p}) \\
(\mathrm{mg} \\
\left.\mathrm{g}^{-1}\right)\end{array}$ & $\begin{array}{c}\mathrm{k}_{2} \\
\text { (g/mgm } \\
\text { in) }\end{array}$ & $\mathrm{R}^{2}$ & 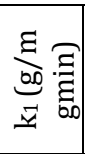 & $u$ & $\approx$ & $\begin{array}{c}\mathrm{t}_{1 / 2} \\
(\mathrm{mi} \\
\mathrm{n})\end{array}$ & & $\begin{array}{c}\text { qe(calc } \\
\text { ul) } \\
(\mathrm{mgg} \\
-1)\end{array}$ & $\begin{array}{c}\mathrm{q}_{\mathrm{e}(\mathrm{ex}} \\
\mathrm{p}) \\
(\mathrm{mg} \\
\left.\mathrm{g}^{-1}\right)\end{array}$ & $\begin{array}{c}\mathrm{k}_{2} \\
\text { (g/mgm } \\
\text { in) }\end{array}$ & $\mathrm{R}^{2}$ & ت્ & $u$ & $\approx$ & \\
\hline \multicolumn{19}{|c|}{ Ads. dos. $\left(\mathrm{gL}^{-1}\right)$} \\
\hline $\begin{array}{l}0, \\
5\end{array}$ & $\begin{array}{c}0,9 \\
2 \\
\end{array}$ & $\begin{array}{c}69,9 \\
3 \\
\end{array}$ & $\begin{array}{l}69, \\
63 \\
\end{array}$ & 0,015 & $\begin{array}{c}1,0 \\
0 \\
\end{array}$ & $\begin{array}{c}0,5 \\
2 \\
\end{array}$ & $\begin{array}{l}63, \\
67 \\
\end{array}$ & $\begin{array}{c}0,8 \\
1 \\
\end{array}$ & 0,96 & $\begin{array}{c}0,9 \\
6 \\
\end{array}$ & $\begin{array}{c}64,1 \\
0 \\
\end{array}$ & $\begin{array}{l}71, \\
52 \\
\end{array}$ & 0,007 & $\begin{array}{c}0,9 \\
8 \\
\end{array}$ & $\begin{array}{c}0,5 \\
5 \\
\end{array}$ & $\begin{array}{l}56, \\
83\end{array}$ & $\begin{array}{c}0,9 \\
0 \\
\end{array}$ & 2,00 \\
\hline $\begin{array}{l}1, \\
0\end{array}$ & $\begin{array}{c}0,9 \\
6\end{array}$ & $\begin{array}{c}36,2 \\
3\end{array}$ & $\begin{array}{l}35, \\
99\end{array}$ & 0,024 & $\begin{array}{c}1,0 \\
0\end{array}$ & $\begin{array}{c}0,3 \\
6\end{array}$ & $\begin{array}{l}31, \\
95\end{array}$ & $\begin{array}{c}0,7 \\
9\end{array}$ & 1,16 & $\begin{array}{c}0,9 \\
4\end{array}$ & $\begin{array}{c}35,8 \\
4\end{array}$ & $\begin{array}{l}35 \\
76\end{array}$ & 0,046 & $\begin{array}{c}1,0 \\
0\end{array}$ & $\begin{array}{c}0,2 \\
4\end{array}$ & $\begin{array}{l}33, \\
14\end{array}$ & $\begin{array}{c}0,7 \\
4\end{array}$ & 0,61 \\
\hline $\begin{array}{l}2, \\
0\end{array}$ & $\begin{array}{c}0,9 \\
6 \\
\end{array}$ & $\begin{array}{c}18,0 \\
5\end{array}$ & $\begin{array}{l}18, \\
02\end{array}$ & 0,13 & $\begin{array}{c}1,0 \\
0 \\
\end{array}$ & $\begin{array}{l}0,0 \\
58 \\
\end{array}$ & $\begin{array}{l}17, \\
34\end{array}$ & $\begin{array}{c}0,8 \\
6 \\
\end{array}$ & 0,43 & $\begin{array}{c}0,9 \\
7 \\
\end{array}$ & $\begin{array}{c}17,9 \\
8 \\
\end{array}$ & $\begin{array}{l}17 \\
93 \\
\end{array}$ & 0,09 & $\begin{array}{c}0,9 \\
9 \\
\end{array}$ & $\begin{array}{c}0,1 \\
0 \\
\end{array}$ & $\begin{array}{l}16, \\
82\end{array}$ & $\begin{array}{c}0,7 \\
7 \\
\end{array}$ & 0,62 \\
\hline \multicolumn{19}{|c|}{ Temp. (K) } \\
\hline $\begin{array}{c}29 \\
1 \\
\end{array}$ & $\begin{array}{c}0,9 \\
4\end{array}$ & $\begin{array}{c}14,1 \\
4\end{array}$ & $\begin{array}{l}14, \\
00\end{array}$ & 0,004 & $\begin{array}{c}1,0 \\
0\end{array}$ & $\begin{array}{c}0,5 \\
7\end{array}$ & $\begin{array}{c}5,6 \\
2 \\
\end{array}$ & $\begin{array}{c}0,9 \\
0\end{array}$ & $\begin{array}{c}17,8 \\
6\end{array}$ & $\begin{array}{c}0,9 \\
3 \\
\end{array}$ & $\begin{array}{c}33,7 \\
8\end{array}$ & $\begin{array}{l}32, \\
96\end{array}$ & 0,002 & $\begin{array}{c}0,9 \\
7 \\
\end{array}$ & $\begin{array}{c}1,2 \\
5\end{array}$ & $\begin{array}{l}15, \\
02\end{array}$ & $\begin{array}{c}0,9 \\
1 \\
\end{array}$ & $\begin{array}{c}15,1 \\
7\end{array}$ \\
\hline $\begin{array}{c}29 \\
8\end{array}$ & $\begin{array}{c}0,9 \\
8\end{array}$ & $\begin{array}{c}36,2 \\
3\end{array}$ & $\begin{array}{l}35, \\
99\end{array}$ & 0,024 & $\begin{array}{c}0,9 \\
9\end{array}$ & $\begin{array}{c}0,3 \\
7\end{array}$ & $\begin{array}{l}31, \\
95\end{array}$ & $\begin{array}{c}0,8 \\
0\end{array}$ & 1,16 & $\begin{array}{c}0,9 \\
5\end{array}$ & $\begin{array}{c}35,8 \\
4\end{array}$ & $\begin{array}{l}35 \\
7\end{array}$ & 0,046 & $\begin{array}{c}1,0 \\
0\end{array}$ & $\begin{array}{c}0,2 \\
4\end{array}$ & $\begin{array}{l}33, \\
14\end{array}$ & $\begin{array}{c}0,7 \\
3\end{array}$ & 0,61 \\
\hline $\begin{array}{c}30 \\
8\end{array}$ & $\begin{array}{c}0,9 \\
4\end{array}$ & $\begin{array}{c}18,6 \\
9\end{array}$ & $\begin{array}{l}18, \\
46\end{array}$ & 0,006 & $\begin{array}{c}0,9 \\
6\end{array}$ & $\begin{array}{c}0,5 \\
0\end{array}$ & $\begin{array}{l}11, \\
54\end{array}$ & $\begin{array}{c}0,9 \\
3\end{array}$ & 9,03 & $\begin{array}{c}0,9 \\
2\end{array}$ & $\begin{array}{c}33,6 \\
7\end{array}$ & $\begin{array}{l}32, \\
30\end{array}$ & 0,003 & $\begin{array}{c}0,9 \\
9\end{array}$ & $\begin{array}{c}1,0 \\
9\end{array}$ & $\begin{array}{l}18, \\
89\end{array}$ & $\begin{array}{c}0,9 \\
2\end{array}$ & $\begin{array}{c}10,3 \\
2\end{array}$ \\
\hline \multicolumn{19}{|c|}{ Initial Con. $\left(\mathrm{mgL}^{-1}\right)$} \\
\hline 37 & $\begin{array}{c}0,9 \\
6\end{array}$ & $\begin{array}{c}36,2 \\
3\end{array}$ & $\begin{array}{l}35, \\
99\end{array}$ & 0,024 & $\begin{array}{c}1,0 \\
0\end{array}$ & $\begin{array}{c}0,3 \\
6\end{array}$ & $\begin{array}{l}31, \\
95\end{array}$ & $\begin{array}{c}0,7 \\
9\end{array}$ & 1,16 & $\begin{array}{c}0,9 \\
4\end{array}$ & $\begin{array}{c}35,8 \\
4\end{array}$ & 35 , & 0,046 & $\begin{array}{c}1,0 \\
0\end{array}$ & $\begin{array}{c}0,2 \\
4\end{array}$ & $\begin{array}{l}33, \\
14\end{array}$ & $\begin{array}{c}0,7 \\
3\end{array}$ & 0,61 \\
\hline 60 & $\begin{array}{c}0,9 \\
6 \\
\end{array}$ & $\begin{array}{c}48,0 \\
7 \\
\end{array}$ & $\begin{array}{l}46, \\
93\end{array}$ & 0,003 & $\begin{array}{c}0,9 \\
8 \\
\end{array}$ & $\begin{array}{c}1,4 \\
2 \\
\end{array}$ & $\begin{array}{l}29, \\
54 \\
\end{array}$ & $\begin{array}{c}0,9 \\
0 \\
\end{array}$ & 7,10 & $\begin{array}{c}0,9 \\
8 \\
\end{array}$ & $\begin{array}{c}41,6 \\
6 \\
\end{array}$ & $\begin{array}{l}41, \\
20 \\
\end{array}$ & 0002 & $\begin{array}{c}0,9 \\
8 \\
\end{array}$ & $\begin{array}{c}1,4 \\
4 \\
\end{array}$ & $\begin{array}{l}21, \\
41\end{array}$ & $\begin{array}{c}0,9 \\
9 \\
\end{array}$ & 0,01 \\
\hline $\begin{array}{c}10 \\
0\end{array}$ & $\begin{array}{c}0,9 \\
6 \\
\end{array}$ & $\begin{array}{c}65,7 \\
8 \\
\end{array}$ & $\begin{array}{l}64, \\
19 \\
\end{array}$ & 0,002 & $\begin{array}{c}0,9 \\
9 \\
\end{array}$ & $\begin{array}{c}2,2 \\
1\end{array}$ & $\begin{array}{l}38, \\
37 \\
\end{array}$ & $\begin{array}{c}0,8 \\
1 \\
\end{array}$ & 7,79 & $\begin{array}{c}0,9 \\
8 \\
\end{array}$ & $\begin{array}{c}59,8 \\
8 \\
\end{array}$ & $\begin{array}{l}57, \\
55\end{array}$ & 0,001 & $\begin{array}{c}0,9 \\
9 \\
\end{array}$ & $\begin{array}{c}2,6 \\
9 \\
\end{array}$ & $\begin{array}{l}23, \\
29 \\
\end{array}$ & $\begin{array}{c}0,9 \\
8 \\
\end{array}$ & $\begin{array}{c}17,3 \\
8\end{array}$ \\
\hline \multicolumn{19}{|c|}{ Initial pH } \\
\hline $\begin{array}{l}3, \\
0\end{array}$ & $\begin{array}{c}0,9 \\
6\end{array}$ & $\begin{array}{c}25,5 \\
7\end{array}$ & $\begin{array}{l}24, \\
91\end{array}$ & 0,003 & $\begin{array}{c}0,9 \\
8\end{array}$ & $\begin{array}{c}0,8 \\
8\end{array}$ & $\begin{array}{l}12, \\
83\end{array}$ & $\begin{array}{c}0,9 \\
2\end{array}$ & $\begin{array}{c}13,3 \\
8\end{array}$ & $\begin{array}{c}0,9 \\
6\end{array}$ & $\begin{array}{c}35,3 \\
3\end{array}$ & $\begin{array}{l}34, \\
59\end{array}$ & 0,008 & $\begin{array}{c}0,9 \\
9\end{array}$ & $\begin{array}{c}0,5 \\
5\end{array}$ & $\begin{array}{l}27, \\
34\end{array}$ & $\begin{array}{c}0,9 \\
1\end{array}$ & 3,61 \\
\hline $\begin{array}{l}5, \\
0\end{array}$ & $\begin{array}{c}0,9 \\
7 \\
\end{array}$ & $\begin{array}{c}27,3 \\
2\end{array}$ & $\begin{array}{l}26, \\
70\end{array}$ & 0,002 & $\begin{array}{c}0,9 \\
7 \\
\end{array}$ & $\begin{array}{c}1,1 \\
1\end{array}$ & $\begin{array}{l}11, \\
05\end{array}$ & $\begin{array}{c}0,9 \\
5\end{array}$ & $\begin{array}{c}18,7 \\
3\end{array}$ & $\begin{array}{c}0,9 \\
6\end{array}$ & $\begin{array}{c}34,8 \\
4\end{array}$ & $\begin{array}{l}34, \\
85 \\
\end{array}$ & 0,007 & $\begin{array}{c}0,9 \\
9\end{array}$ & $\begin{array}{c}0,6 \\
4\end{array}$ & $\begin{array}{l}26, \\
91\end{array}$ & $\begin{array}{c}0,9 \\
2\end{array}$ & 4,10 \\
\hline $\begin{array}{l}7, \\
0\end{array}$ & $\begin{array}{c}0,9 \\
6\end{array}$ & $\begin{array}{c}19,6 \\
0\end{array}$ & $\begin{array}{l}19, \\
28\end{array}$ & 0,002 & $\begin{array}{c}0,9 \\
9\end{array}$ & $\begin{array}{c}0,9 \\
1\end{array}$ & $\begin{array}{c}5,6 \\
2 \\
\end{array}$ & $\begin{array}{c}0,9 \\
2\end{array}$ & $\begin{array}{c}25,9 \\
3\end{array}$ & $\begin{array}{c}0,9 \\
2\end{array}$ & $\begin{array}{c}32,7 \\
8\end{array}$ & $\begin{array}{l}31, \\
85\end{array}$ & 0,001 & $\begin{array}{c}0,9 \\
6\end{array}$ & $\begin{array}{c}1,2 \\
6\end{array}$ & $\begin{array}{l}13, \\
82\end{array}$ & $\begin{array}{c}0,8 \\
5\end{array}$ & $\begin{array}{c}31,4 \\
0\end{array}$ \\
\hline $\begin{array}{l}9, \\
0\end{array}$ & $\begin{array}{c}0,9 \\
1\end{array}$ & $\begin{array}{c}16,4 \\
7 \\
\end{array}$ & $\begin{array}{l}14, \\
13\end{array}$ & 0,001 & $\begin{array}{c}0,6 \\
8\end{array}$ & $\begin{array}{c}0,9 \\
5\end{array}$ & $\begin{array}{c}0,6 \\
3\end{array}$ & $\begin{array}{c}0,8 \\
9\end{array}$ & $\begin{array}{c}70,7 \\
7\end{array}$ & $\begin{array}{c}0,9 \\
2\end{array}$ & $\begin{array}{c}32,3 \\
6\end{array}$ & $\begin{array}{l}31, \\
29\end{array}$ & 0,001 & $\begin{array}{c}0,9 \\
4\end{array}$ & $\begin{array}{c}1,3 \\
8\end{array}$ & $\begin{array}{l}10, \\
66\end{array}$ & $\begin{array}{c}0,8 \\
6\end{array}$ & $\begin{array}{c}31,9 \\
6\end{array}$ \\
\hline
\end{tabular}




\subsubsection{ADSORPTION THERMODYNAMICS}

Thermodynamic parameters of FLQ adsorption on different temperatures and adsorbents are given in Table 5 . $\Delta G^{\circ}$ values Eq. (7) and the temperature range of 291-308 K showing the spontaneous nature of the adsorption process. The negative values of $\Delta \mathrm{G}^{\circ}$ indicated the applicability of the sorption process and the positive values of $\Delta \mathrm{H}^{\circ}$ and $\Delta \mathrm{S}^{\circ}$ showed that the sorption process was endothermic in nature and had a random increase in the solid / liquid interface, respectively, during the sorption process. The positive value of $\Delta \mathrm{S}$ showed good affinity of the material with dye molecules and showed an increase in the degree of freedom of the adsorbed species [65].

Table 5: Thermodynamic parameters of FLQ adsorption on different temperatures and adsorbents

\begin{tabular}{|c|c|c|c|c|c|}
\hline Adsorbents & $\mathrm{T}(\mathrm{K})$ & $\begin{array}{c}\Delta \mathrm{G}^{\mathrm{o}} \\
\left(\mathrm{kJmol}^{-1}\right)\end{array}$ & $\begin{array}{c}\Delta \mathrm{H}^{\mathrm{o}} \\
\left(\mathrm{kJmol}^{-1}\right)\end{array}$ & $\begin{array}{c}\Delta \mathrm{So}^{\circ} \\
\left(\mathrm{Jmol}^{-1}\right)\end{array}$ & $\mathrm{R}^{2}$ \\
\hline \multirow[t]{3}{*}{$A C$} & 291 & $-8,501$ & \multirow[t]{3}{*}{75,083} & \multirow[t]{3}{*}{282,76} & \multirow[t]{3}{*}{0,99} \\
\hline & 298 & $-8,930$ & & & \\
\hline & 308 & $-8,998$ & & & \\
\hline \multirow[t]{3}{*}{ MagAC } & 291 & $-4,747$ & \multirow[t]{3}{*}{56,543} & \multirow[t]{3}{*}{211,34} & \multirow[t]{3}{*}{0,96} \\
\hline & 298 & $-9,291$ & & & \\
\hline & 308 & $-5,825$ & & & \\
\hline \multirow[t]{3}{*}{ SBS/MagAC } & 291 & 1,201 & \multirow[t]{3}{*}{20,993} & \multirow[t]{3}{*}{72,58} & \multirow[t]{3}{*}{0,89} \\
\hline & 298 & $-8,853$ & & & \\
\hline & 308 & 0,008 & & & \\
\hline \multirow[t]{3}{*}{ PC/MagAC } & 291 & $-5,078$ & \multirow[t]{3}{*}{123,837} & \multirow[t]{3}{*}{434,82} & \multirow[t]{3}{*}{0,99} \\
\hline & 298 & $-8,329$ & & & \\
\hline & 308 & $-4,942$ & & & \\
\hline
\end{tabular}

Using the kinetic. adsorption and thermodynamic data. it was concluded that physical adsorption in the polymer network and chemical interaction of the OTC molecules via ion-exchange were both involved in the adsorption process.

\section{CONCLUSION}

The data obtained as part of this study show that AC, MagAC, SBS/MagAC and PC/MagAC can be used as adsorbents to remove FLQ from wastewater streams. Scanning electron microscopy (SEM), X-ray diffraction (XRD) analysis and Brunauer Emmett Teller (BET) measurements were applied for the structural characterization of all adsorbent materials. Adsorption isotherms, kinetic and thermodynamic calculations were conducted to investigate the adsorption potential of all adsorbents for the removal of FLQ from aqueous solution. The optimisation of adsorption process was conducted by insetigating the effects of different parameters, for example, solid-liquid ratio, solution temperature, intial FLQ concentration and solution $\mathrm{pH}$. It was observed that the adsorption capacity, acidic and neutrality positively affected. During the adsorption process, the main adsorption mechanisms are thought to be electrostatic interaction, ion exchange, $\pi-\pi$ bond interaction, aromaticity and H-bonding and hydrophobic interaction. In conclusion, the adsorbent materials which were prepared and used in this study can be used effectively for the removal of FLQs from wastewater streams due to their chemical structure, high adsorption capacity and environmental friendliness.

\section{SOURCES OF FUNDING}

This research received no specific grant from any funding agency in the public, commercial, or not-for-profit sectors. 
Mehmet Uğurlu, Huseyn Osman, Ali imran Vaizoğullar, and Abdul Chaudhary

\section{CONFLICT OF INTEREST}

The author have declared that no competing interests exist.

\section{ACKNOWLEDGMENT}

This study was financially supported as a project (19/081/01/1/1) by Research Project Coordination Unit. Muğla Sitkı Koçman Üniversity. Mehmet Uğurlu declares that he has no conflict of interest. Mehmet Uğurlu has received research grants from Research Project Coordination Unit Muğla Sitkı Koçman Üniversity. Mehmet Uğurlu is currently working as a Professor in the Department of Chemistry, Faculty of Science, Muğla Sitki Kocman University, 48000 Muğla, TURKEY. This article does not contain any studies with human or animal subjects performed by the any of the authors. The authors declare that they have no conflict of interest and they are academic staff members of Higher Education Institutions (HEI) in Turkey and UK.

\section{REFERENCES}

[1] Murray., A. Örmeci., B. Environ. Sci. Pollut. R (2012) vol 193, p. 820-3830.

[2] Terzić, S., Senta, I., Ahel, M., Gros, M., Petrović, M., Barcelo, D., ... \& Jabučar, D. (2008). Occurrence and fate of emerging wastewater contaminants in Western Balkan Region. Science of the total environment, 399(1-3, 66-77.

[3] Parshikov á I., Freeman á A. J. P., Williams A. J., Moody á J. D., Sutherland J. B. Appl Microbiol Biotechnol (1999) vol. 52 p. 553-557.

[4] Nieto, J., Freer, J., Contreras, D., Candal, R.J., Sileo, E.E., Mansilla, H.D., J. Hazard. Mater. (2008) vol. 15545 p. 50

[5] Nowara, A., Burhenne, J., Spiteller, M., J. Agr. Food Chem. 1997 vol. 45, p. 1459-1463.

[6] Zhang, H., Huang, CH. Chemosphere (2007) vol. 66 p. 1502-1512.

[7] Sotelo, J.L., Rodríguez, A., Mestanza, M., Díez, S., Álvarez, S., García, J. J. Environ. Sci. Health Part B (2012) vol. 47640 p. 652.

[8] Juan L., Acero, F., Javier Benitez., Francisco J., Real, Fernando Teva, Chemical Engineering Journal 210 (2012)1-8

[9] Zhang, H., \& Huang, C. H. Chemosphere, (2007). Vol. 66(8, p. 1502-1512.

[10] Paul, T., Liu, J., Machesky, M. L., \& Strathmann, T. J. Journal of colloid and interface science, (2014) vol. 428, p. 63-72.

[11] Sotelo, J. L., Ovejero, G., Rodríguez, A., Álvarez, S., \& García, J. Chemical engineering journal, (2013). Vol. 228, p. 102-113.

[12] Guaita, D. P., Sayen, S., Boudesocque, S., \& Guillon, E. Journal of colloid and interface science, (2011) vol. $357(2$, p. 453-459.

[13] Álvarez-Torrellas, S., Ribeiro, R. S., Gomes, H. T., Ovejero, G., \& García, J. Chemical Engineering Journal, (2016) vol. 296, p. 277-288.

[14] Wang, J., Hu, J., \& Zhang, S. Journal of colloid and interface science, (2010) vol. 349(2, p. 578-582.

[15] Adams, C., Wang, Y., Loftin, K., \& Meyer, M. (2002) vol. 128(3, p. 253-260.

[16] Asfaram, A., Ghaedi, M., Goudarzi, A., \& Rajabi, M. Dalton Transactions, (2015) vol. 44(33, p. 14707-14723.

[17] Shaker, M. A., \& Yakout, A. A. Spectrochimica Acta Part A: Molecular and Biomolecular Spectroscopy, (2016). Vol. 154, p. 145-156.

[18] Ghaedi, M., Khafri, H. Z., Asfaram, A., \& Goudarzi, A. Spectrochimica Acta Part A: Molecular and Biomolecular Spectroscopy, (2016) vol. 152, p. 233-240..

[19] Davarnejad, R., \& Panahi, P. Separation and Purification Technology, (2016) vol. 158, p. 286-292.

[20] Akın, D., Yakar, A., \& Gündüz, U. Synthesis of Magnetic Fe304-Chitosan Nanoparticles by Ionic Gelation and Their Dye Removal Ability. Water Environment Research, (2015). vol. 87(5, p. 425-436.

[21] Bagheri, A. R., Ghaedi, M., Asfaram, A., Bazrafshan, A. A., \& Jannesar, R. Comparative study on ultrasonic assisted adsorption of dyes from single system onto Fe304 magnetite nanoparticles loaded on activated carbon: experimental design methodology. Ultrasonics sonochemistry, (2017) vol. 34, p. 294-304. 
Fluoroquinolones Antibiotics Adsorption onto Polymer Coated Magnetic Nanoparticular Activated Carbon

[22] Bhatia, D., Datta, D., Joshi, A., Gupta, S., \& Gote, Y. Adsorption study for the separation of isonicotinic acid from aqueous solution using activated carbon/Fe304 composites. (2018). Journal of Chemical \& Engineering Data, vol. 63(2, p. 436-445.

[23] Zhang, S., Wang, Z., Chen, H., Kai, C., Jiang, M., Wang, Q., \& Zhou, Z. Polyethylenimine functionalized Fe304/steam-exploded rice straw composite as an efficient adsorbent for Cr (VI) removal. Applied Surface Science, (2018). Vol. 440, 1p. 277-1285.

[24] Badi, M. Y., Azari, A., Pasalari, H., Esrafili, A., \& Farzadkia, M. Modification of activated carbon with magnetic Fe304 nanoparticle composite for removal of ceftriaxone from aquatic solutions. Journal of Molecular Liquids, (2018). Vol. 261, p. 146-154.

[25] Wen, T., Wang, J., Yu, S., Chen, Z., Hayat, T., \& Wang, X. Magnetic porous carbonaceous material produced from tea waste for efficient removal of As (V, Cr (VI, humic acid, and dyes. ACS Sustainable Chemistry \& Engineering, (2017). Vol. 5(5, p. 4371-4380.

[26] Kim, E. A., Seyfferth, A. L., Fendorf, S., \& Luthy, R. G. Immobilization of Hg (II) in water with polysulfide-rubber (PSR) polymer-coated activated carbon. water research, (2011). Vol. 45(2, p. 453-460.

[27] Yang, N., Zhu, S., Zhang, D., \& Xu, S. Synthesis and properties of magnetic Fe304-activated carbon nanocomposite particles for dye removal. Materials Letters, (2008). Vol. 62(4-5, p. 645-647.

[28] Kakavandi, B., Jonidi, A., Rezaei, R., Nasseri, S., Ameri, A., \& Esrafily, A. Synthesis and properties of Fe $304-$ activated carbon magnetic nanoparticles for removal of aniline from aqueous solution: equilibrium, kinetic and thermodynamic studies. Iranian journal of environmental health science \& engineering, (2013). Vol. 10(1, p. 1-9.

[29] Fard, M. A., Vosoogh, A., Barkdoll, B., \& Aminzadeh, B. Using polymer coated nanoparticles for adsorption of micropollutants from water. Colloids and Surfaces A: Physicochemical and Engineering Aspects, (2017). Vol. 531, p. 189-197.

[30] Lagergren, S. K. (1898). About the theory of so-called adsorption of soluble substances. Sven. Vetenskapsakad. Handingarl, 24, 1-39.

[31] Ho, Y. S., \& McKay, G. Pseudo-second order model for sorption processes. Process biochemistry, (1999). Vol. 34(5, p. 451-465.

[32] Acemioğlu, B. Batch kinetic study of sorption of methylene blue by perlite. Chemical Engineering Journal, (2005). Vol. 106(1, p. 73-81.

[33] Uğurlu, M. Kinetic of the adsorption of reactive dyes by using sepiolite mineral. Microporous and Mesoporous Materials, (2009). Vol. 119, p. 276-283.

[34] Ugurlu, M. Adsorption studies and removal of nitrate from bleached kraft mill effluent by fly-ash and sepiolite. Fresenius Environmental Bulletin, (2009). Vol. 18(12, p. 2328-2335.

[35] Girgis, B. S., Temerk, Y. M., Gadelrab, M. M., \& Abdullah, I. D. X-ray diffraction patterns of activated carbons prepared under various conditions. Carbon letters, (2007). Vol. 8(2, p. 95-100.

[36] Vaizoğullar, A. İ. TiO2/ZnO supported on sepiolite: preparation, structural characterization, and photocatalytic degradation of flumequine antibiotic in aqueous solution. Chemical Engineering Communications, (2017). Vol. 204(6, p. 689-697.

[37] Oliveira, G. F. D., Andrade, R. C. D., Trindade, M. A. G., Andrade, H. M. C., \& Carvalho, C. T. D. Thermogravimetric and spectroscopic study (TG-DTA/FT-IR) of activated carbon from the renewable biomass source babassu. Química Nova, (2017). Vol .40(3, p. 284-292.

[38] Uğurlu, M., Gürses, A., \& Açıkyıldız, M. Comparison of textile dyeing effluent adsorption on commercial activated carbon and activated carbon prepared from olive stone by $\mathrm{ZnCl} 2$ activation. Microporous and Mesoporous Materials, (2008). Vol. 111(1-3, p. 228-235.

[39] UĞURLU, M., YILMAZ, S. İ., \& VAİZOĞULLAR, A. Removal of Color and COD from Olive Wastewater by Using Three-Phase Three-Dimensional (3D) Electrode Reactor. Materials Today: Proceedings, (2019). Vol. 18, p. 1986-1995.

[40] Mazloomi, F., \& Jalali, M. Ammonium removal from aqueous solutions by natural Iranian zeolite in the presence of organic acids, cations and anions. Journal of Environmental Chemical Engineering, (2016). Vol. $4(1$, p. $240-249$.

[41] Wang, Y., Lu, J., Wu, J., Liu, Q., Zhang, H., \& Jin, S. Adsorptive removal of fluoroquinolone antibiotics using bamboo biochar. Sustainability, (2015). Vol. 7(9, p. 12947-12957. 
[42] Duan, W., Li, M., Xiao, W., Wang, N., Niu, B., Zhou, L., \& Zheng, Y. Enhanced adsorption of three fluoroquinolone antibiotics using polypyrrole functionalized Calotropis gigantea fiber. Colloids and Surfaces A: Physicochemical and Engineering Aspects, (2019). Vol. 574, p. 178-187.

[43] Gu, C., \& Karthikeyan, K. G. Sorption of the antimicrobial ciprofloxacin to aluminum and iron hydrous oxides. Environmental science \& technology, (2005). Vol. 39(23, p. 9166-9173.

[44] Cao, E., Duan, W., Wang, A., \& Zheng, Y. Oriented growth of poly (m-phenylenediamine) on Calotropis gigantea fiber for rapid adsorption of ciprofloxacin. Chemosphere, (2017). Vol. 171, p. 223-230.

[45] Duan, W., Wang, N., Xiao, W., Zhao, Y., \& Zheng, Y. Ciprofloxacin adsorption onto different micro-structured tourmaline, halloysite and biotite. Journal of Molecular Liquids, (2018). Vol. 269, p. 874-881.

[46] Van Wieren, E. M., Seymour, M. D., \& Peterson, J. W. Interaction of the fluoroquinolone antibiotic, ofloxacin, with titanium oxide nanoparticles in water: adsorption and breakdown. Science of the Total Environment, (2012). Vol. 441, p.1-9.

[47] Wang, B., Jiang, Y. S., Li, F. Y., \& Yang, D. Y. Preparation of biochar by simultaneous carbonization, magnetization and activation for norfloxacin removal in water. Bioresource technology, (2017). Vol. 233, p. 159-165.

[48] Yang, W., Lu, Y., Zheng, F., Xue, X., Li, N., \& Liu, D. Adsorption behavior and mechanisms of norfloxacin onto porous resins and carbon nanotube. Chemical engineering journal, (2012). Vol. 179, p. 112-118.

[49] Fu, H., Li, X., Wang, J., Lin, P., Chen, C., Zhang, X., \& Suffet, I. M. Activated carbon adsorption of quinolone antibiotics in water: Performance, mechanism, and modeling. Journal of environmental sciences, (2017). Vol. 56, p. 145-152.

[50] Wang, F., Yang, B., Wang, H., Song, Q., Tan, F., \& Cao, Y. Removal of ciprofloxacin from aqueous solution by a magnetic chitosan grafted graphene oxide composite. Journal of Molecular Liquids, (2016). Vol. 222, p. 188194.

[51] Gao, Y., Li, Y., Zhang, L., Huang, H., Hu, J., Shah, S. M., \& Su, X. Adsorption and removal of tetracycline antibiotics from aqueous solution by graphene oxide. Journal of colloid and interface science, (2012). Vol. 368(1, p. 540546.

[52] Tang, Y., Guo, H., Xiao, L., Yu, S., Gao, N., \& Wang, Y. Synthesis of reduced graphene oxide/magnetite composites and investigation of their adsorption performance of fluoroquinolone antibiotics. Colloids and Surfaces A: Physicochemical and Engineering Aspects, (2013). Vol. 424, p. 74-80.

[53] Barbosa, J., Barron, D., Cano, J., Jimenez-Lozano, E., Sanz-Nebot, V., \& Toro, I. Evaluation of electrophoretic method versus chromatographic, potentiometric and absorptiometric methodologies for determing $\mathrm{pKa}$ values of quinolones in hydroorganic mixtures. Journal of pharmaceutical and biomedical analysis, (2001). Vol. 24(5-6, p. 1087-1098.

[54] Zhang, H., \& Huang, C. H. Adsorption and oxidation of fluoroquinolone antibacterial agents and structurally related amines with goethite. Chemosphere, (2007). Vol. 66(8, p. 1502-1512.

[55] Conkle, J. L., Lattao, C., White, J. R., \& Cook, R. L. Competitive sorption and desorption behavior for three fluoroquinolone antibiotics in a wastewater treatment wetland soil. Chemosphere, (2010). Vol. 80(11, p. 1353-1359.

[56] Gu, C., \& Karthikeyan, K. G. Interaction of tetracycline with aluminum and iron hydrous oxides. Environmental science \& technology, (2005). Vol. 39(8, p. 2660-2667.

[57] Sotelo, J. L., Ovejero, G., Rodríguez, A., Álvarez, S., \& García, J. Analysis and modeling of fixed bed column operations on flumequine removal onto activated carbon: $\mathrm{pH}$ influence and desorption studies. Chemical engineering journal, (2013). Vol. 228, p. 102-113.

[58] Ötker, H. M., \& Akmehmet-Balcıoğlu, I. Adsorption and degradation of enrofloxacin, a veterinary antibiotic on natural zeolite. Journal of Hazardous Materials, (2005). 122(3, 251-258.

[59] He, X., Wang, B., \& Zhang, Q. Phenols removal from water by precursor preparation for MgAl layered double hydroxide: Isotherm, kinetic and mechanism. Materials Chemistry and Physics, (2019). 221, 108-117.

[60] Ahmed, M. J., \& Theydan, S. K. Fluoroquinolones antibiotics adsorption onto microporous activated carbon from lignocellulosic biomass by microwave pyrolysis. Journal of the Taiwan Institute of Chemical Engineers, (2014). Vol. 45(1, p. 219-226.

[61] Leal, R. M. P., Alleoni, L. R. F., Tornisielo, V. L., \& Regitano, J. B. Sorption of fluoroquinolones and sulfonamides in 13 Brazilian soils. Chemosphere, (2013). Vol. 92(8, p. 979-985. 
[62] Ji, L., Chen, W., Duan, L., \& Zhu, D. Mechanisms for strong adsorption of tetracycline to carbon nanotubes: a comparative study using activated carbon and graphite as adsorbents. Environmental science \& technology, (2009). Vol. 43(7, p. 2322-2327.

[63] Renault, F., Morin-Crini, N., Gimbert, F., Badot, P. M., \& Crini, G. Cationized starch-based material as a new ion-exchanger adsorbent for the removal of CI Acid Blue 25 from aqueous solutions. Bioresource technology, (2008). Vol. 99(16, p. 7573-7586.

[64] Duan, W., Li, M., Xiao, W., Wang, N., Niu, B., Zhou, L., \& Zheng, Y. Enhanced adsorption of three fluoroquinolone antibiotics using polypyrrole functionalized Calotropis gigantea fiber. Colloids and Surfaces A: Physicochemical and Engineering Aspects, (2019). Vol. 574, p. 178-187.

[65] El Yacoubi, A., Rahali, N., Elmerras, D., Rezzouk, A., \& El Idrissi, B. C. Removal of Methylene Blue Dye by Adsorption on Natural Sand. American Journal of Environment and Sustainable Development, (2019). Vol. $4(2$, p. 84-88. 